\title{
Archipel
}

ARCHIPEL Études interdisciplinaires sur le monde insulindien

99 | 2020

Varia

\section{An 'Indies' Couple: Colonial Communities and Issues Surrounding Identity in the Dutch East Indies, ca. 1890-1930s}

Un couple " des Indes »: les communautés coloniales et les questions d'identité dans les Indes orientales néerlandaises, de c.1890 aux années 1930

\section{G. Roger Knight}

\section{OpenEdition}

Journals

\section{Electronic version}

URL: http://journals.openedition.org/archipel/1709

DOI: 10.4000/archipel. 1709

ISSN: 2104-3655

\section{Publisher}

Association Archipel

\section{Printed version}

Date of publication: 15 July 2020

Number of pages: $153-188$

ISBN: 978-2-910513-83-2

ISSN: 0044-8613

\section{Electronic reference}

G. Roger Knight, "An 'Indies' Couple: Colonial Communities and Issues Surrounding Identity in the Dutch East Indies, ca. 1890-1930s", Archipel [Online], 99 | 2020, Online since 02 June 2020, connection on 15 March 2021. URL: http://journals.openedition.org/archipel/1709; DOI: https://doi.org/10.4000/ archipel. 1709 


\section{G. ROGER KNIGHT ${ }^{l}$}

\section{An 'Indies' Couple: Colonial Communities and Issues Surrounding Identity in the Dutch East Indies, ca. 1890- 1930s}

In the early 1900s, the Dutch writer Cornelia Margaretha Vissering (1859$1942)^{2}$ paid a lengthy visit to her brother and his family in Batavia, the capital of the erstwhile Dutch East Indies. As an author whose travel writings had been appearing in various magazines since around the turn of the century, Vissering evidently wanted to see more of the Indies than Batavia and its immediate environs and in September 1907 she and her female travelling companion found themselves in the East Java hill station of Sukapura in the mountain range that contained the highest of Java's many volcanoes. It was at Sukapura that she paid a call one evening on a woman, her children and their governess, who were staying in a villa nearby the one in which she was lodged. She included a brief account of the visit in her subsequently published narrative of A Journey through East Java (1912) from which, although she is not named, it is possible to identify the woman concerned as Johanna Elizabeth Bezoet de Bie (1874-1957), wife of the administrateur or general manager of a sugar factory down on the plain. ${ }^{3}$ The 'campaign' or manufacturing season had not

1. Visiting Research Fellow, Department of History/School of Humanities, University of Adelaide, South Australia 5005. Email: roger.knight@adelaide.edu.au.

2. Vissering was born in the Dutch university town of Leiden, where her father Simon Vissering (1818-1888) was a former university professor whose career also embraced journalism and a period as Minister of Finance in The Hague. She was the elder sister of Gerard Vissering (1865-1937), who had qualified as a lawyer before taking up a career in banking. She disembarked in Batavia in March 1907 and sailed back to Europe in April 1908.

3. C. M Vissering, Een Reis door Oost-Java, Haarlem, Boon, 1912: 78 (its publication 
yet ended there, so that while his family had been able to retreat to the cool of the hills, her absent husband would have had to remain at his post.

Her host that evening, Vissering told her readers, was a creole - that is say, colonial-born - woman, and since (as she remarked) women of this ilk were often disparaged in the Netherlands, she was at pains to set the record straight: 'surrounded by her children, [she] received us with that certain easy friendliness which is characteristic of the refined class [to which she belonged], her personality distinguished by/expressed through [munt uit door] the particular beauty of her countenance, her stateliness of posture, the elegance of her dress and her good manners.' Nonetheless, the woman concerned might have been less impressed by Vissering's apparent assumption that she was not only colonial-born but also of mixed ethnicity: in describing the family's governess - a blond English woman - she drew an explicit contrast between her and the 'darker' complexion of her employer and 'the dark eyes and almost jet-black hair' of her offspring' ${ }^{4}$ In fact, in a reversal of the more usual situation among the colonial Dutch, while she herself laid claim to be a 'full-blood' European (as colonial terminology would have it), it was Bezoet de Bie's husband, Alexander MacNeill (1871-1937), who was Eurasian: an individual of part-Scots ancestry who had been christened in tribute to his Highlander grandfather.

Taking its cue from the implications of Vissering's vignette of early twentieth century colonial life, the discussion that follows concerns the way in which that Scottish heritage was refracted through the lens of what the Dutch invariably referred to as 'the Indies'. The paper begins with a brief reconstruction of the background of the married couple concerned and their life at a factory near the East Java town of Probolinggo around the turn of the twentieth century. It continues by elaborating on aspects of creole community life in the Indies, and in particular on the characteristic pervasiveness of regular family formation and sociability: 'Being Dutch in the Indies's - and on the key island of Java in particular - was very much at odds with the transient expatriate-ness often associated, however problematically, with European 'sojourner colonialism' elsewhere in Asia. The argument turns, however, on the extent to which the couple sought to differentiate - even distance - themselves from an archetypical Indisch environment. Literally 'of the Indies' and redolent

had been preceded by De Kust van Smaragd, Bohn, Haarlem, 1910). Vissering subsequently published a further book about the Indies: Het Land Van Jan Pieterszoon Coen, Den Haag, Van Stockum, 1925. See also: https://dbnl.org/auteurs/auteur. php?id=viss135 accessed 9-7-18.

4. Vissering, Oost-Java: 178.

5. Ulbe Bosma and Remco Raben, Being "Dutch" in the Indies: A History of Creolisation and Empire, 1500-1920, Singapore, NUS Press, 2008 (originally in Dutch as De Oude Indische Wereld [The Old Indies World] 1500-1920, Amsterdam, Bert Bakker, 2003). 
of an 'Old Indies World' that was part-myth and part-social reality, Indisch was heavily imbued with hybrid social and cultural meanings and, as such, a designation that is the beginning of an exploration rather than its terminus. ${ }^{6}$ In so doing, it underscores the complexity and fluidity of diasporic identities that, as Georgina Tsolidis has remarked, 'carry a sense of somewhere else into multiple migration, destinations and ways of being', while at the same time challenging 'the monogamy of place' and 'de-stabilising our understanding of "home". 7 As such, they are - and were - a constant work-in-progress.

Inter alia, that 'work-in-progress' is multi-faceted, and dependent on a variety of media. In the particular case of Bezoet de Bie and MacNeill, however, the paucity of contemporary letters, memoirs and the like throws into stark relief issues surrounding the charting of identity through the medium of photographs, a great many of which have been happily preserved in the family's 'archive'. ${ }^{8}$ Ego documents of this particular kind are, as Susie Protschky has suggested, 'often the only autobiographical material that ...people have left to posterity' and tend to take on 'a life of their own' ${ }^{9}$ Indeed, it makes sense to talk quite emphatically about the agency of photograph, which are far from being 'mere' illustrations of lives predominantly delineated by other media. In this context, of course, as Elisabeth Edwards reminds us, the apparent 'beguiling realism' of the photograph can all too easily lead to the conclusion that 'photographic inscription' is somehow unmediated and sufficiently selfevident as to render interpretation superfluous, whereas, in reality, 'the threads wrapped around, entangling photographs and making histories... are as much to "think with" as they are evidential, empirical inscriptions'. ${ }^{10}$ As such,

6. For a sampling of the very extensive literature here, see Vincent J. Houben, 'Boundaries of Race: Representations of Indisch in Colonial Indonesia Revisited', in Harald Fischer-Tine \& Susanne Gehrmann (eds), Empires and Boundaries. Rethinking Race, Class and Gender in Colonial Settings, New York and London, Routledge, 2009:66-85.

7. Georgina Tsolidis, 'Introduction', in Georgina Tsolidis (ed.), Migration, Diaspora and Identity. Cross-National Experiences, Dordrecht \& Heidelberg, Springer, 2014: 3-4.

8. The present story draws heavily on the family's photographic 'archive', amounting to several informal collections of photographs, located in both the Netherlands and Australia. Supplemented by a rich trove of written documentation authored by subsequent family members late in the twentieth century, it is in the possession of present day MacNeill family descendants In The Hague and in Melbourne, to whom the author is profoundly grateful both for the generous provision of access and for their convivial support.

9. Susie Protschky, 'Tea Cups, Cameras and Family Life: Picturing domesticity in Elite European and Javanese Family Photographs from the Netherlands Indies, ca.1900-1942', History of Photography, 36, 1 (2012): 44 \& 47; Susie Protschky, 'Photography, Modernity and the Governed in Late Colonial Indonesia,' in Protschy (ed.), Photography, Modernity and the Governed in Late Colonial Indonesia, Amsterdam, Amsterdam University Press, 2015: 11-40.

10. Elizabeth Edwards, Raw Histories. Photographs, Anthropology and Museums, 
they play a key role in what has been termed 'the imaginative geography' of empire ${ }^{11}$ - and in the construction of diasporic identity among empire's colonisers. That construction is crucially enmeshed, in short, not only with the archive created by the written word - important as it is to the narrative that follows - but also with the photographic one. ${ }^{12}$ Unsurprisingly, what latter-day commentators have termed the 'colonial gaze' is an unmistakeable dimension of photographs that are 'saturated' - as are most of its kind - with the 'asymmetry [inherent] within colonial relationships'. ${ }^{13}$ Among other things, that gaze largely circumscribed the material foundations - in this case the work of thousands of Indonesian men, women and children in sugar fields and factory - of colonial life. Yet, it would be perverse to concentrate solely on what is absent in the photographs at the expense of what is so richly present, and of what they have to tell us about the social framework in which - and for which - the photographs in question were created.

\section{A Creole Couple: Johanna Bezoet de Bie and Alexander MacNeill}

Both MacNeill's and Bezoet de Bie's fathers were well-to-do business people, who had made their fortunes in the Indies, married locally and established families there before relocating to the metropole at the beginning of the 1890s. ${ }^{14}$ Subsequently, both settled in The Hague, the Dutch city most favoured by 'returnees' on account of its rich Indies associations and presence of hundreds of other Indischgasten or Old Indies Hands as well as scores of

Oxford, Berg, 2001: 7-10; Elizabeth Edwards and Janice Hart, 'Introduction: photographs as objects', in Edwards and Hart (eds), Photographs Objects Histories, New York \& London, Routledge, 2004: 1-15.

11. James R. Ryan, Picturing Empire. Photography and the Visualization of the British Empire, London, Reaktion Books, 1997: 11-27. For a recent, insightful development of this argument, see Sophie Junge, 'Groet uit Java: Picture Postcards and the Transnational Making of the Colony around 1900,' History of Photography, 42,2 (2018): 168-184.

12. For classic published collections of photographs relating to the Dutch communities of nineteenth and early twentieth century Indonesia, see E. Breton de Nijs, Tempo Doeloe, Amsterdam, Querido, 1961; Nieuwenhuys, Komen en Blijven, Amsterdam, Querido 1982; Nieuwenhuys, Baren en Oudgasten, Amsterdam, Querido, 1981. For more recent compilations and (revisionist) commentary, see Liane van der Linden et al., Toekang Potret. 100 Jaar fotographie in Nederlands Indie, 1839-1939/100 years of photography in the Dutch Indies, Amsterdam, Fragment, 1989 and Liesbeth Owehand, Herinneringen in Beeld: Fotoalbums uit Nederlands-Indie, Leiden, KITLV, 2009.

13. Protschky, Photography, Modernity and the Governed: 19.

14. Supporting genealogical data relating to the MacNeill-Bezoet de Bie family, friends and associates in the pages that follow can be located by entering the names concerned on the Dutch genealogical websites Open Archief, Genealogie Online, Wie was Wie and similar sites, including that of the Centraal Bureau voor Genealogie in Den Haag. Exceptions are indicated in the footnotes, as are the sources of newspaper data available through the Netherlands Royal Library's DELPHER website. 


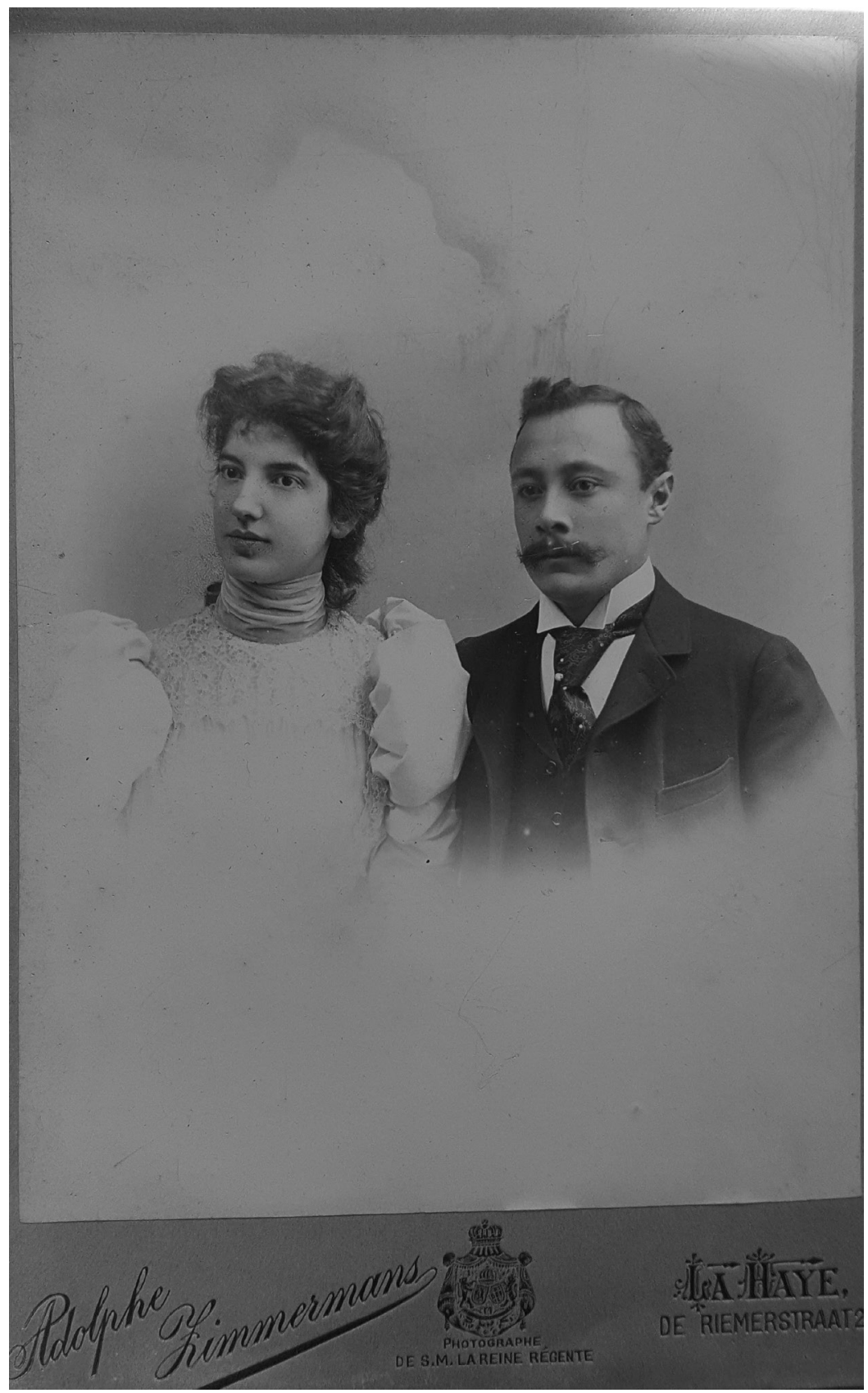

Fig. 1. Johanna Bezoet de Bie and Alexander MacNeill, The Hague, 1897. 
temporary leave-takers. ${ }^{15}$ Hence, when the couple sailed for the Indies after their wedding in the city in February 1897, unlike many such newly-weds for whom, 'going out' to the colony was a venture into the relatively unknown, they were returning to familiar territory, where both had spent their early years. Indeed, Bezoet de Bie had remained in the colony until her sixteenth year, before moving with the rest of her family to the Netherlands, while MacNeill had been sent there once he reached his teens to continue his education at the HBS (Hoogere Burgerschool or Senior High School) at Arnhem in the east of country.

On a number of other counts, however, the couple's family background was strikingly contrasted. The bride's father, Hermann Bezoet de Bie (18441915), scion of a mercantile family established in the great Dutch commercial and shipping centre of Rotterdam, had been taken by his parents to the Indies as a youth of around sixteen early in the 1860s. ${ }^{16}$ Reaching adulthood in Surabaya and following the premature death there of his father in 1865 , he set up in business in the city in the wholesale import-export trade: indeed, he evidently made enough of a success of it to marry an Indies-born woman, Sara Sijthoff (1848-1934), the daughter of an Indies government official who had spent most of his life in the colony and his Indies-born wife. Despite this strongly creole background, Johanna Bezoet de Bie nonetheless laid claim to genetically totally Dutch parentage: Indeed, late in life she reportedly spoke disparagingly (they were 'unpleasant') of those among her cousins who were both Indies-born and indubitably of mixed ethnicity. ${ }^{17}$

Her husband's father, Richard MacNeill (1842-1915) came, however, from precisely that background, though it seems likely that such things were invested with more significance by later generations than they were at the time. The son of a migrant Scots trader based in the major port of Semarang on the north coast of Central Java and a Javanese woman - known to us only

15. Maarten van Doorn, Het leven gaat er een lichten gang. Den Haag in de Jaren 1919-1940, Zwolle, Waanders, 2002: 39-52; Coos Versteeg, 'Er is maar een echte Indische buurt', in Esther Captain et al., De Indische Zomer in Den Haag, Leiden KITLV Uitgeverij, 2005: 23-40; Suzanne de Graaf, 'Iets van een Vreemde Vrucht': Indische Verlofgangers in Nederland, 1919-1939, Masterscriptie, Universiteit Leiden, 2009.

16. Peter Christiaans, 'Bezoet de Bie', De Indische Navorscher: Jaarboek 2008: 134140 .

17. Personal communication Mevrouw Elizabeth del Court Konig van Essen, The Hague, June 2017. (Johanna Bezoet de Bie-Mac Neill was Mevrouw del Court's greataunt). For aspects of the disparagement of creole women of mixed ethnicity in general, see Petra Boudewijn, "You Must Have Inherited This Trait from Your Eurasian Mother": The Representation of Mixed-race Characters in Dutch Colonial Literature', Dutch Crossing, 40:3 (2016), 239-260 and Boudewijn's extended treatment of the subject in Petra Boudewijn, Warm Bloed. De Representatie van Indo-Europeanen in de Indische-Nederlandse Letterkunde (1860-Heden), Hilversum, Verloren, 2016. 


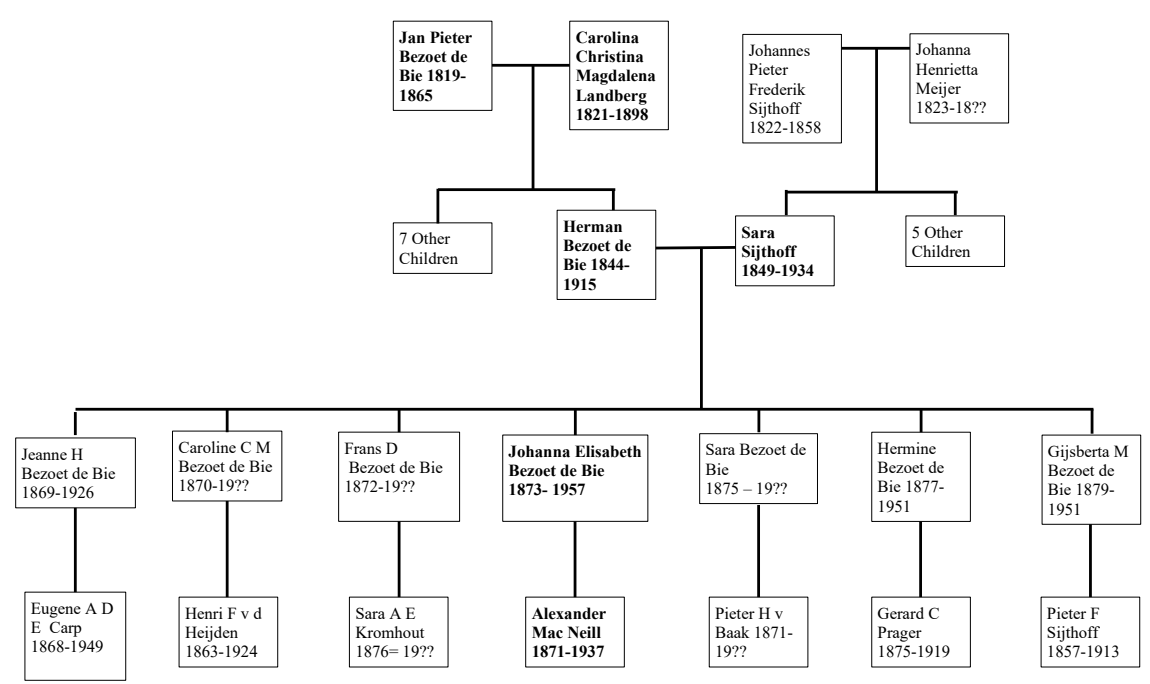

Fig. 2. Bezoet de Bie family tree.

as "the free Javanese woman Sienok"18 - with whom he had co-habited during his lengthy sojourn there, Richard MacNeill had been taken to Europe by his repatriating father late in the 1840s. Returning to the Indies almost a decade later - and to a job in his father's old firm in Central Java - he subsequently relocated in the mid-1860s from Semarang to the East Java 'sugar town' of Probolinggo. Once established there, he cemented his position in colonial society by marrying Wilhelmina Couperus (1849-1874), the likewise Eurasian daughter of Resident Petrus Theodorus Couperus (1815-1872), whose posting to Probolinggo had concluded a long career in the Indies government service that had taken him from his Indies birthplace in Batavia to various parts of the outlying island of Sumatra before terminating in the Oosthoek (the Dutch term for Java's Eastern Salient) in 1862. ${ }^{19}$

18. Haagsgemeetearchief /Huwelijksacte Richard Mac Neill- Johanna Margaretha Augusta Hubner, 20.10. 1906 via Openarchief [OA]. 'Sienok' is most probably a variant of 'Si Nok, Sinok', a Javanese term of endearment for a little girl, something like 'la petite', 'the little one'.

19. W. Wijnaendts van Resandt, 'De Indische Tak van de Familie Couperus,' De Indische Navorscher 5 (1992): 1-8. 


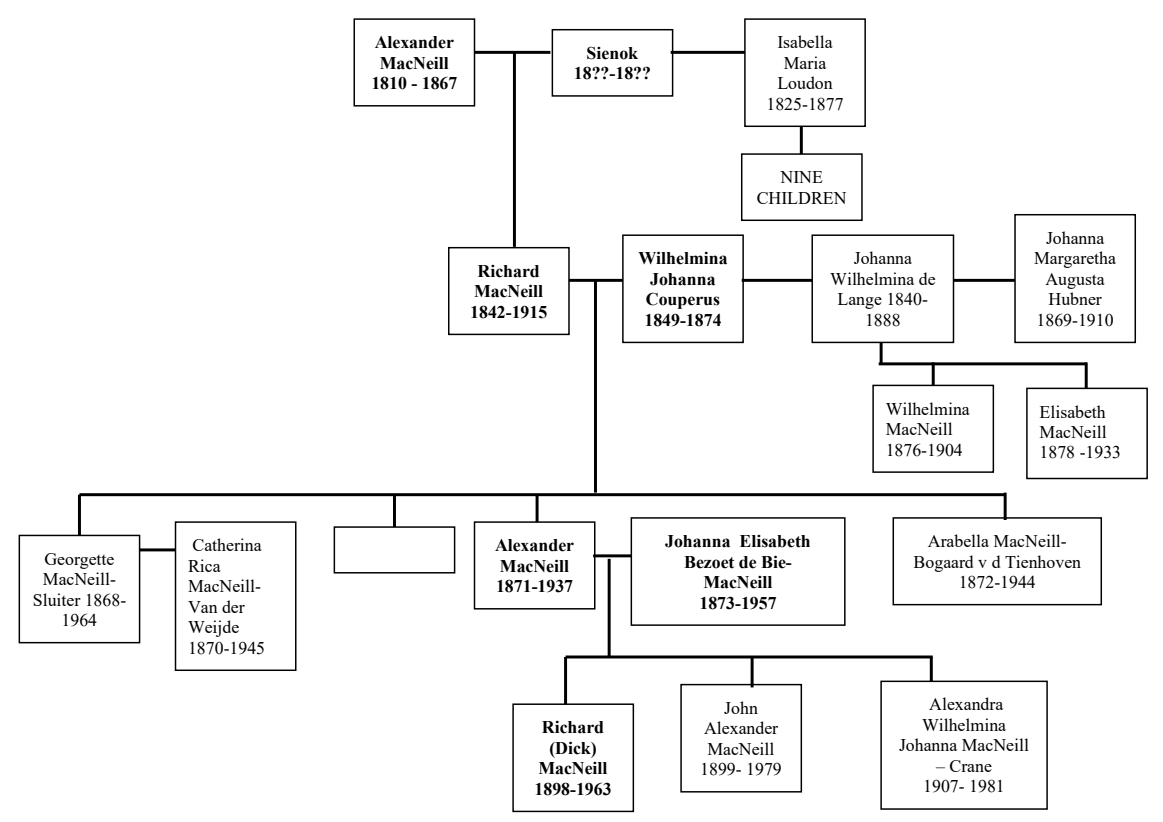

Fig. 3. MacNeill family tree.

\section{'In the Sugar': the Tuan and Nyonya Besar of Oemboel}

Although they came from rather different backgrounds, Johanna Bezoet de Bie and Alexander MacNeill belonged, as the tuan besar ['big man'] and as the nyonya besar (the Indies equivalent of the famed memsahib of British India), to a creole elite that was heavily represented among the owners and managers of the Java sugar industry - from the late nineteenth century through the 1930s the foremost branch of colonial export production in the Indies. By the time he married, in 1897, MacNeill himself had been employed in this industry for some seven years, following no doubt in the footsteps of his maternal uncle, John Couperus (1855-1889), who appears to have spent most of his adult life at sugar factories in the Oosthoek ${ }^{20}$. Latterly, MacNeill had been a tuinemployee (a kind of plantation-overseer), ${ }^{21}$ a position that gave him responsibility for supervising, through a team of Indonesian mandur or foremen, the large numbers of Indonesian labourers of both sexes, casually employed on day wages and of varying degrees of skill, who comprised the great bulk of the industry's field workforce.

20. Wijnaendts van Resandt, 'Familie Couperus': 6.

21. De Locomotief, 08.01.1898. 
Supervisory positions of this kind usually went to locally-born creoles, pre-eminently Eurasian, rather than to 'raw' expatriate Dutchmen who had little familiarity with the rural Javanese environment and less still with its language: young MacNeill, brought up in the locality during his early years and no doubt speaking at least some rudimentary Javanese - 'kitchen Javanese' best describes it - that he would have learnt from his babu or nurse and the other, numerous servants in his parents' household, would notionally have been well suited to the job. Local knowledge was critical. For example, a similarly placed man working at an adjacent factory was said to be particularly adept at managing the labourers under his control because of his 'outstanding command of Madurese', the native tongue of many of the seasonal workers who streamed across the strait from their home island during the sugar campaign in the Oosthoek. For the most part, such supervisors had only modest formal qualifications - this man had basic primary education [lagere school] and a diploma of sorts from one of the 'sugar schools' that the industry ran in East and Central Java - and quickly reached the limits of their promotability. $^{22}$

In MacNeill's case, however, the Eurasian individual concerned was able to cross the boundary into the industry's managerial elite by virtue, it can safely be assumed, of his European education and his (Eurasian) father's wealth and position in industry circles, something that enabled the latter to secure for his son a position, at the tender age of twenty-seven, as administrateur or general manager of a sugar factory on the outskirts of Probolinggo, in which he had a major financial stake. Broadly speaking, only the resident and assistentresident stood above the administrateur in the colonial pecking-order in the countryside, though the bupati (aka the regent), the highest ranking of the hierarchy of local-level Javanese officials, may have laid claim to a similar, superior status. MacNeill and Bezoet de Bie's prestigious position, in turn, placed them at the helm of an enterprise whose history was embedded in the very fabric of Dutch colonialism in Java.

Known as Oemboel, the factory in question had already been in existence for more than sixty years when MacNeill and Bezoet de Bie arrived there early in 1898, and had a history that reflected a variety of transnational diasporic experiences. Building on foundations laid by Sino-Indonesian entrepreneurs who were very active in this part of the Oosthoek in the opening decades of the nineteenth century, ${ }^{23}$ during the 1830 s newly arrived European concessionaires effectively took possession of the industrialised manufacture of sugar in the area. Backed by the Indies Government and (so it might appear) by the

22. Nationaal Archief, Den Haag [hereafter NA]: 2.20.02.03, Archief Cultuurmaatschappij Wonolangan.

23. Claudine Lombard-Salmon, 'The Han Family of East Java. Entrepreneurship and Politics (18th-19th Centuries)', Archipel 41 (1991): 53-87. 


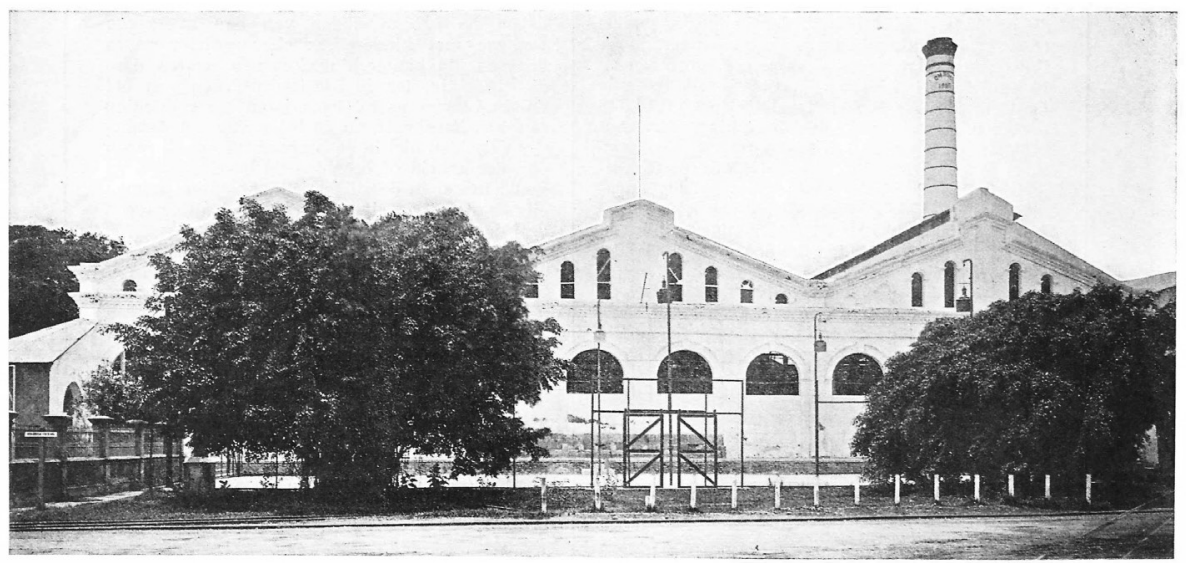

Fig. 4. Oemboel sugar factory, Probolinggo, ca. 1910.

Surabaya 'sister house' of the Maclaine Watson mercantile concern in which Alexander MacNeill's father and grandfather had both been partners, ${ }^{24}$ they had set up Oemboel and two other factories in the Oosthoek, one situated, as was Oemboel itself, just outside the town of Probolinggo and known as Wonolangan and a second, Wringin Anom, situated further along the coast in neighbouring Besoeki Residency. Most such concessionaires were either Dutch or Sino-Indonesian, but in this case they were British people by the name of Etty. Though originally from Yorkshire in the north of the UK, the Etty 'clan' - the term seems appropriate given the sheer number of kin variously located - were also to be found in British India, the Indies and the Netherlands. One family member was the noted mid-Victorian painter William Etty (1787-1849), most of whose adult life was spent in London, while in the Dutch province of Gelderland the money from sugar bought his Netherlandsdomiciled cousins and their descendants a fine villa on the outskirts of the city of Nijmegen as well as a grand house in the suburbs of nearby Arnhem. ${ }^{25}$

Back in the Indies, where they had significant presence over three or more generations, the Java domiciled members of the Etty family could lay claim to being 'pioneers' who owned and ran a sugar-manufacturing business that was first of its kind in Java to have installed innovatory apparatus for 'boiling' cane juice into sugar by steam in a partial vacuum (and thereby contributing to the

24. NA, Archief Ministerie van Kolonien 2697, Besluit GG 2.8.1847/5; Anon, 'De Cultuurmaatschappij Wonolangan (1895-1925), Indie. Geillustreerd 'Tijdschrijft voor Nederland en Kolonien, 9/19 (December 1925): 306-340.

25. Ulbe Bosma, Indiegangers, Amsterdam, Bert Bakker, 2010: 87. https://www. geldersarchief.nl/.../archieven/?mivast; www.molenbeke.nl/wp-content/uploads/.../ Molenbeker-Editie-3.pd. 
both the quantity and quality of their output). By the closing decades of the nineteenth century, however, the whole Etty enterprise was rather outdated: during Alexander MacNeill's tenure as administrateur, however, Oemboel (together with the two other 'Etty' factories) was extensively re-equipped (and re-financed) by McNeill père - inter alia with up-to-the-minute machinery from the celebrated German Hallesche Maschinenfabrik. Technological improvements of this kind no doubt help explain why, under MacNeill's management, productivity at Oemboel rose by at least one third. Gross output, meanwhile, had been boosted by the buying-in of substantial quantities of cane from peasant growers to supplement that produced on the factory's own plantations. ${ }^{26}$

Integral to these developments was a major reconstruction of ownership, very much under Richard McNeill's guidance it must be assumed, which transformed hitherto family proprietorship into a publicly-listed, limited liability company (the Dutch term is NV or Naamloze Vennootschap). Along with the two other 'Etty' sugar factories, Oemboel became part of the Wonolangan Plantation Company (Wonolangan Cultuurmaatschappij) with a head office in the Netherlands and a board of Netherlands-based directors among whom the elder MacNeill was prominent. Also on the board, however, were members of the old proprietor's family (who included the board's first chairman), ${ }^{27}$ so that the Etty connection with Oemboel was far from extinguished by the manifestation of new-style business 'modernity' and (notional) metropolitan control that was typical of virtually the whole of the Java industry by the closing decades of the nineteenth century.

Indeed, and very much in line with these 'survivals', from a social perspective, it was not what was new at Oemboel but what was old that was fundamental to an understanding of its location in the colonial world. During the Etty's long tenure there, twenty members of the family - husbands, wives and children - were domiciled at one or other of their three factories. Nine members of the family were married there, predominantly to locally born men or women; seven were born there; and five died there. ${ }^{28}$ The women of the Etty family were prominent in this history. Some eleven lived there at various times as wives and daughters over a period extending from the 1830s to the 1890 s, and women were also among the owners of the enterprise. ${ }^{29}$ It

26. Koloniaal Verslag, 'Gravenhage, Landsdrukkerij, 1900, Bijl.TT \& 1911, Bijl. JJ. 27. See: Soerabaijasch Handelsblad [hereafter SHB] 17.10.1895; SHB 17.12.1897; Het Locomotief 31.12.1901; Handboek voor Cultuur-en Handelsondernemingen in Nederlandsch-Indie, Amsterdam, De Bussy, 1888-1940 [hereafter HCHO] 22 (1910): 809.

28. 'Pedigree of Etty', at https://cyc.sdp.sirsidynix.net.uk/client/en GB/search/ asset/1018300; P.C. Bloys van Treslong Prins, Genealogische en Heraldische Gedenkwaardigheden betreffende Europeanen op Java, 4 vols, Batavia, Albrechts/ Koninklijke Drukkerij de Unie, 1934-9, 1: 370-371.

29. HCHO 6 (1893-4): 222, 434, 44; SHB 17.10.1895; Anon, 'Wonolangan': 306-340; 
was a granddaughter, moreover, of one of the enterprise's founders, Elisabeth Adriana (Annie) Etty (1863-1949), who maintained the family connection with the Wonolangan Company well into the twentieth century, through her husband Johan Albert Cornelis Sleijster (1862-1912) and his fellow board member, business-associate and distant kinsman Herman Louis Woltersom (1851-1920).

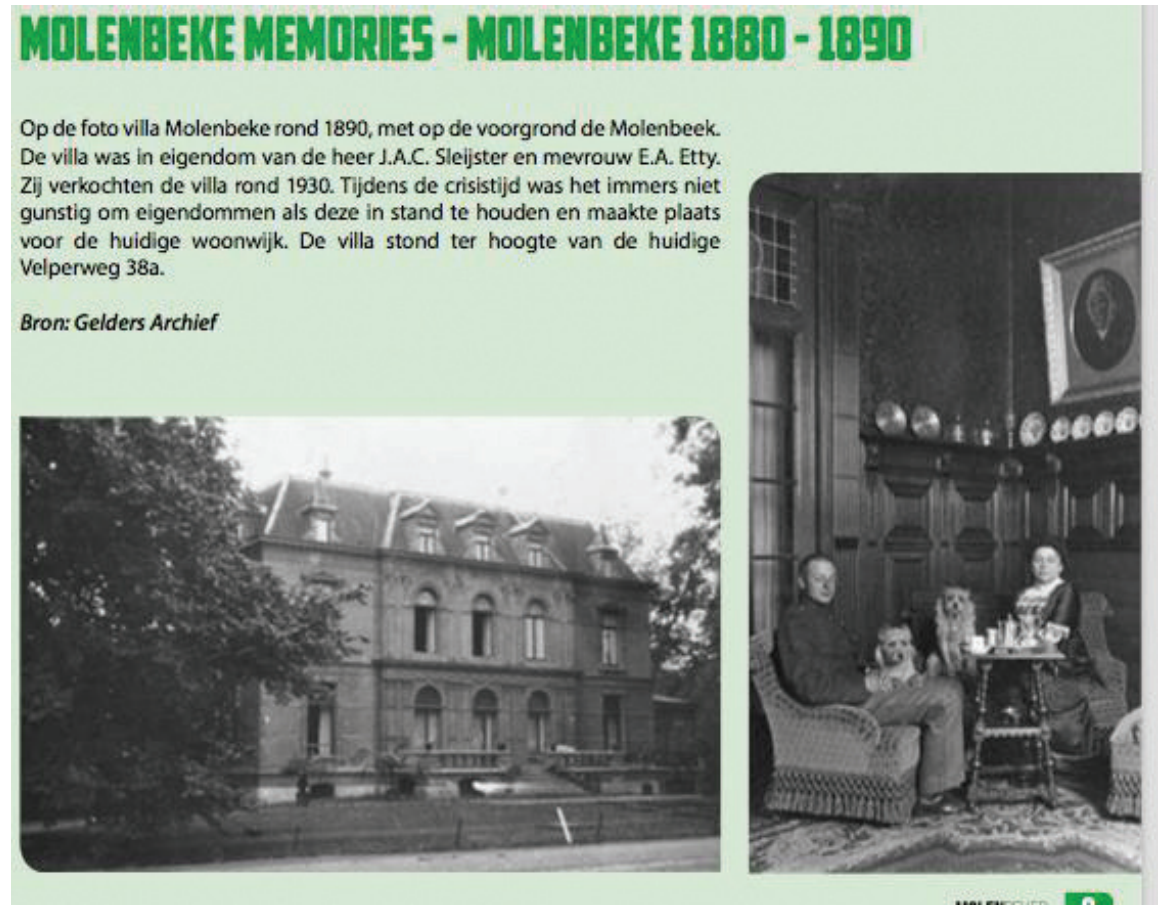

Fig. 5. The Sleijster-Etty couple In Molenbeek (Arnhem), ca. 1900.

Women were also memorialized in the history of the 'Etty' factories in other ways. As identified by a contemporary commemorative plaque, was a 'Miss A. Grant' - most likely a descendent of founder Charles Etty's wife, Elisabeth Grant née Leal or Lyall (1782-1868) - who paid for the construction in 1893 of a substantial swimming pool inside the factory compound at Oemboel. ${ }^{30}$ It was evidently a social centre for the European personnel of the surrounding district - and remained such for decades. In the mid-1930s, for example, an item in a colonial newspaper recorded the setting up of a 'club' to keep the pool open after the factory itself had closed down. In the past,

Leonard Robinson, (with a Foreword by Tom Etty) William Etty: the Life and Art, Jefferson [North Carolina] and London, Macfarland \& Co, 2007: 310.

30. Bloys, Genealogische en Heraldische Gedenkwaardigheden 1: 259. 
it was noted, Oemboel's European staff and their guests had made full and much appreciated use of the facility. Indeed, another such report (two years earlier), told of the attendees at a staff party held to celebrate the opening of the campaign at the still-open Wonolangan factory driving over to the pool at Oemboel for afternoon tea and a swim. ${ }^{31}$

\section{Creole Domesticity: Husbands, Wives, Marriage and Family}

MacNeill and Bezoet de Bie belonged to a social and cultural milieu strikingly different from that of the social world of young single males, open domestic arrangements, Indonesian nyai or 'native' housekeeperconcubines, and the social isolation of European women married to senior managers said to be typical of similar, commodity-producing and westernowned enterprises in more recently settled parts of the Indies. In the latter, a markedly expatriate ethos prevailed. Inter alia, the younger personnel were prevented by company regulations from marrying until they had obtained a significant degree of seniority, something which in turn worked against them finding marriage partners among the creole population of the Indies (instead, they were encouraged to take a 'native housekeeper') - and promoted the (eventual) search for a similarly expatriate wedded partner while on leave in the Netherlands. ${ }^{32}$

At old-established enterprises like Oemboel, however, a profoundly different social ethos prevailed. Bezoet de Bie herself would have experienced a degree of family sociability in East Java broadly comparable to that she would have enjoyed at 'home' in the Netherlands. Of her five sisters, two had likewise married 'into the sugar' and were settled in East Java; a third married the owner-manager of a steam-driven rice-mill on the not-so-distant island of Lombok; while another had wed a junior army officer who subsequently took his bride with him to the Indies. ${ }^{33}$ Nor was this a final count. Over at the nearby Wonolangan factory the administrateur, the Netherlands-born Johannes Sluiter (b. 1869) was also very much 'family', since his wife - the couple had married in Surabaya in 1895 - was Georgette MacNeill (18681964), Alexander MacNeill's elder sister. Indeed, one of the most delightful of the images in the 'archive' is of children's bath time at Oemboel, soon after the turn of the century depicting three infants and their mothers among whom is certainly the njonja and her first-born, and (most probably) two of her sisters who had also started their families in the Indies.

31. Indische Courant [herafter IC], 16.4.1935; SHB 11.05.1933.

32. E.g., Laura Anne Stoler, 'Re-thinking Colonial Categories: European Communities and the Boundaries of Rule', Comparative Studies in Society and History, 31 (1989): $144-5$.

33. Christiaans, 'Bezoet de Bie': 136-7. 


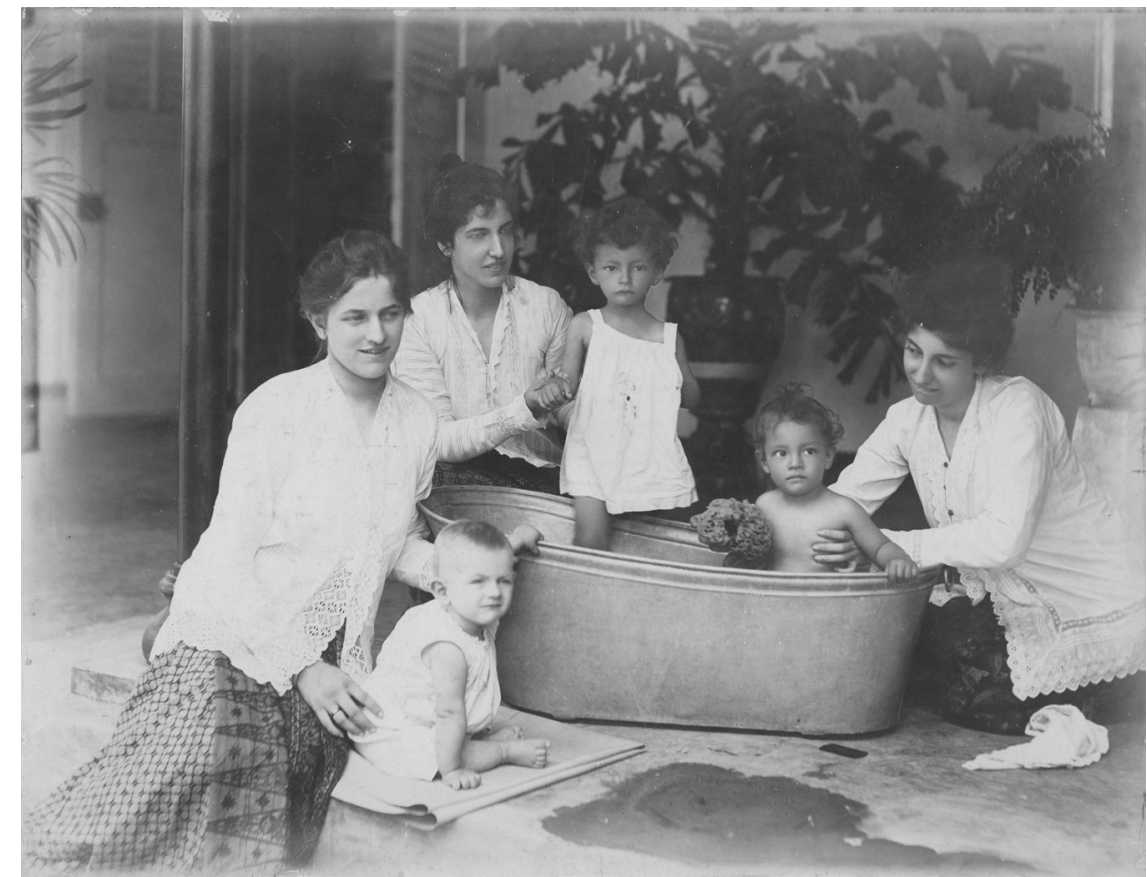

Fig. 6. Children's bath-time at Oemboel, early twentieth century.

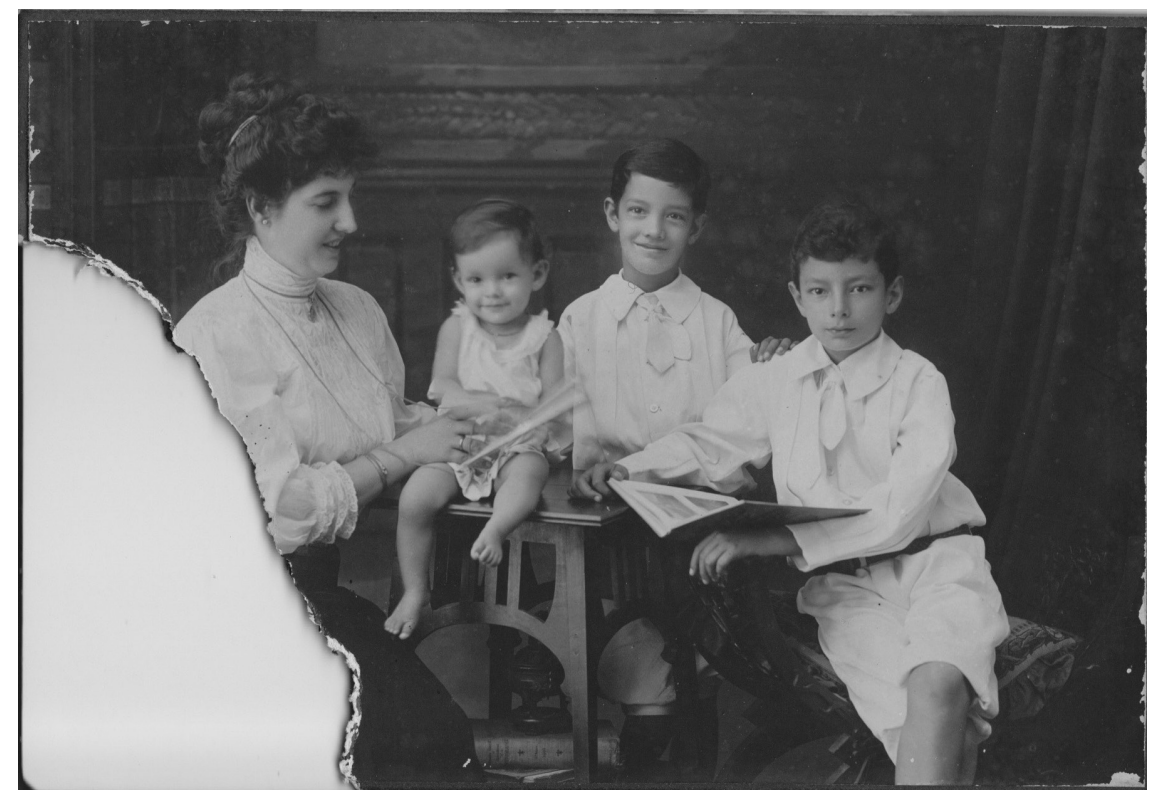

Fig. 7. Johanna Bezoet de Bie and her three children. 
Creole domesticity and sociability, enshrined in regular family formation, was the order of the day not only in the case of the MacNeill-Bezoet de Bie couple but also, and more generally, among Oemboel's European staff of managers, supervisors, engineers and technicians, people referred to in the Dutch sources as the personeel (personnel). ${ }^{34}$ The majority were creoles born in the Indies, many of whom were married, usually to other creoles. At the close of the 1920s, for example, a complete account of the European personnel of all three of the Wonolangan Company's sugar factories - including Oemboel - showed that of the one hundred and four individuals currently employed, around two-thirds [67] had been born in the Indies (of the remaining third [37] all but four individuals heralded from the Netherlands). At the same time, a clear majority [60] of the personnel were married men, of whom creoles accounted for two thirds [41]. ${ }^{35}$ Moreover, The total number of the three factories' European personnel would, no doubt, have included a number of very young men (or youths) who were, in effect, below marriageable age, thereby inflating the numbers of 'unmarried' men among the personeel as a whole. For example, Alexander MacNeill himself would have been barely eighteen when he was sent back to Java to a junior position at an East Java factory early in 1891 .

We need to move beyond the immediate confines of the Oemboel factory, however, to grasp more fully the settled character of the colonial community in which MacNeill and Bezoet de Bie were embedded during their lengthy sojourn in Probolinggo. In terms of origin and ethnicity, let alone social standing, that community generally was a diverse one. Nonetheless, some clues to the anatomy of at least its social and economic elite is provided by what we know of the membership of the town's Veritas Masonic Lodge, into which Alexander MacNeill (following in the footsteps of his grandfather who had been a leading member of the Lodge in Semarang in the 1840s) was initiated soon after his arrival at Oemboel at the close of the 1890s. MacNeill's fellow Masons would most likely have been the people among whom the administrateur of Oemboel and his wife circulated in and around Probolinggo - and most of them (on the evidence of name and occupation preserved in the Lodge's membership lists) were people who, whether colonial-born creoles or not, could best be classified as 'settlers' rather than as 'expatriates' or, in contemporary Dutch parlance, trekkers: they were people, that is to say, for whom the Indies was, predominantly, a place of permanent domicile. ${ }^{36}$ In

34. See e.g., G. Roger Knight, 'A Sugar Factory and its Swimming Pool: Incorporation and Differentiation in Colonial Java', Ethnic and Racial Studies, 24 (3), 2001: 451471.

35. NA, 2.20.02.03, Archief Cultuurmaatschappij Wonolangan, file 156, Conduite Staten 1929-31.

36. The writer is deeply grateful to Mijnheer Jac. Piepenbrock of Het Cultureel Maconniek Centrum 'Prins Frederik', Den Haag, for kindly facilitating access to 


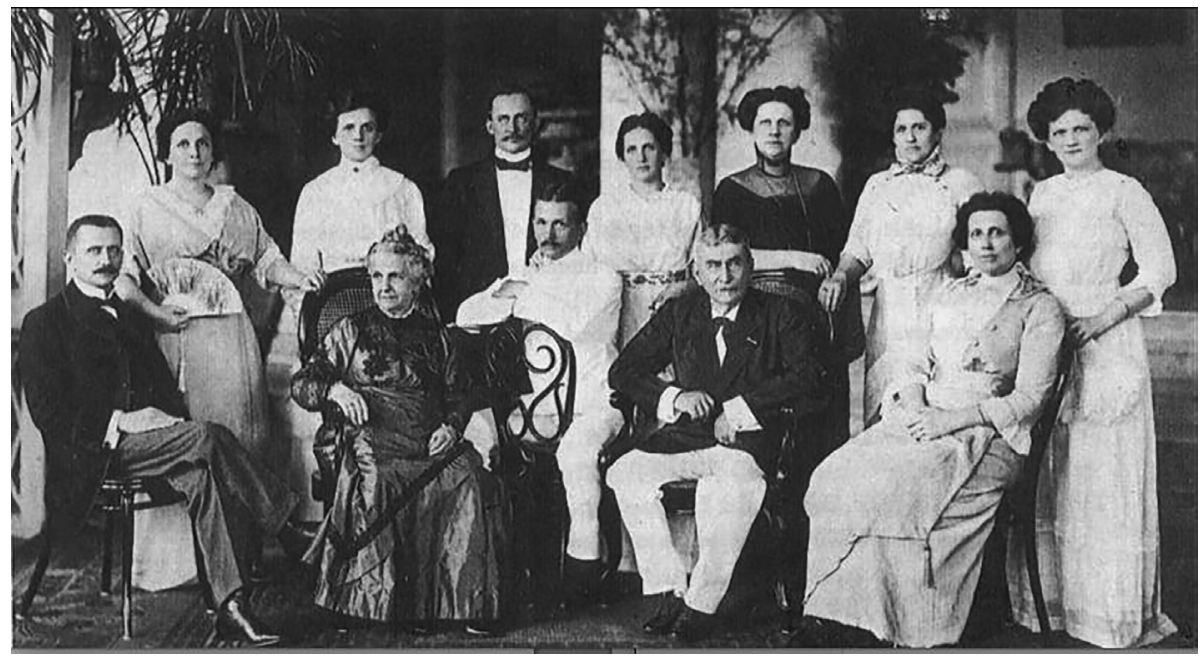

Fig. 8. The Thal Larsen family, Probolinggo ca. 1914.

short, while it might be assumed that the lower social and economic strata of Probolinggo's colonial community was likely to be composed of creoles for whom the Indies was patently 'home', the same would also appear to be largely true of its upper echelons.

To be sure, there were no doubt individuals who fitted into the 'trekker' or transient mould. The majority, however, seem to have been individuals of a rather different stripe. Among them were members of the Larsen family, proprietors of the oldest established (c. 1867) European mercantile concern in the town.

Danish in origin, the pater familias Rasmus Samuel Thal Larsen (18371928), together with his Amsterdam-born wife, Johanna Bernardina Levert (1842-1926), had settled in the Oosthoek in their twenties and died there in their eighties, as did the leading coffee planters at Loemadjang in Probolinggo's mountainous hinterland, the step brothers Jean Guillaume Renardel de Lavalette (1828-1918) and Gerrit Christiaan Renardel de Lavalette (18491926). The MacNeill-Bezoet-de-Bie couple are likely to have known them well, as MacNeill's aunt - his late mother's younger sister - was married to the estate's administrateur. ${ }^{37}$ The elder of the two Lavalette brothers had married an Indies-born woman, Sie Poddie (d.1909) - she was presumably of Sino-Indonesian origin - and their only child, Margaretha Johanna Cornelia Renardel de Lavalette (1849-1939), had herself married locally to an

archival materials relating to the historic membership of the Veritas lodge and to Dr. Tom van den Berge of the KITLV, Leiden, for his sage advice and assistance.

37. Wijnaendts van Resandt, 'Familie Couperus': 6. 
'expatriate' Dutchman and - like him - spent the rest of her life in the colony. Others had even more pronounced settler credentials. The sugar factory administrateur Robert Erland Nicolai Soesman (1868-1919), for example, was a long-term 'blijver' whose forebears had first arrived in the colony in the 1820s. ${ }^{38}$ How well MacNeill and Bezoet de Bie fitted into this broad pattern of settler colonials is something to which we can now turn.

\section{Slippery Identities in the Diaspora}

In discussing the history of the Dutch colonial communities in eighteenth century Java, Jean Taylor used the phrase 'slippery identities' ${ }^{39}$ and although the context and circumstances differed significantly at locations like Oemboel a hundred years or more later, the concept itself remains valid. In the specific case of the MacNeill-Bezoet de Bie couple, moreover, 'identity' was further complicated by their combined Celtic-Dutch-Indies heritage. Possessors of a Scots family name but only partial Celtic ancestry, the MacNeill couple were also the product of a colonial environment in Asia in which heterogeneity and hybridity were prominent features. What stands out, nonetheless, is the extent to which the couple sought to differentiate - even distance -themselves from the Indisch environment of the Indies colonial world in which they found themselves. Such at least is one implication of some of the photographic evidence in the family's 'archive'. Nor, as we shall see, does that evidence exist in isolation. Of course, this was not a simple 'either/or' determination, any more than was the case throughout the upper echelons, at least, of the Indies' creole communities in general, where multiple identities predominated. Even so the Indisch hybridity of the two individuals concerned - both of them Indies-born and one of them the offspring of a Eurasian mother and father offered only imperfect clues to how the couple perceived their place in the colonial environment from which both of them stemmed.

A number of the photographs in the 'archive' do indeed contrive to transport the viewer to the Indies - and to do so in a manner broadly congruent with what one pioneering writer on the subject suggested was the quintessential function of such image making, in which colonial subjects are represented in certain conventional, subordinate ways. ${ }^{40}$ One shows the MacNeill's two sons in a

38. For Renardel de Lavalette see e.g.,: https://www.geni.com/people/Paul-AntoineRenardel-de-Lavalette/6000000060824446927; http://www.uwstamboomonline. $\mathrm{nl} /$ passie/sites/template.php?pid=12291108; daktari.antenna.nl/gebhard.htm. For Tal Larsen, see e.g.,. Indische Courant 11.01.1928. For Soesman, see e.g., https:// gw.geneanet.org/mmeisenbacher?lang=en\&n=soesman\&oc=0 \&p=abraham+eliza.

39. Jean Gelman Taylor, 'Slippery Identities: Race, religion and destiny in 17 th and 18 th century Java,' in Joost J. Coté and Loes Westerbeek (eds), Recalling the Indies. Colonial Culture and Postcolonial Identities, Amsterdam, Askant, 2005: 29-46.

40. Ryan, Picturing Empire: 11-12. The only surviving photograph in the family's collection to show Indonesians outside the servant class depicts a wedono or district head - a key Javanese official of the colonial state on whom the Oemboel factory would 


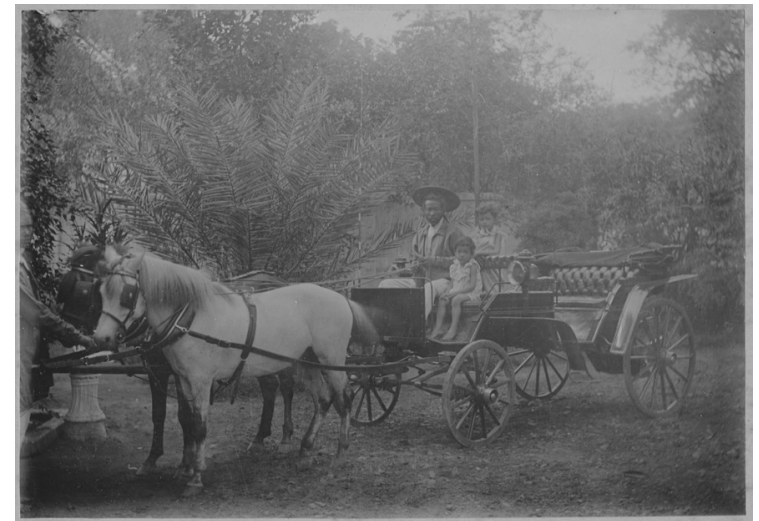

Fig. 9. The MacNeill-Bezoet de Bie couple's two sons in a barouche, with coachman.

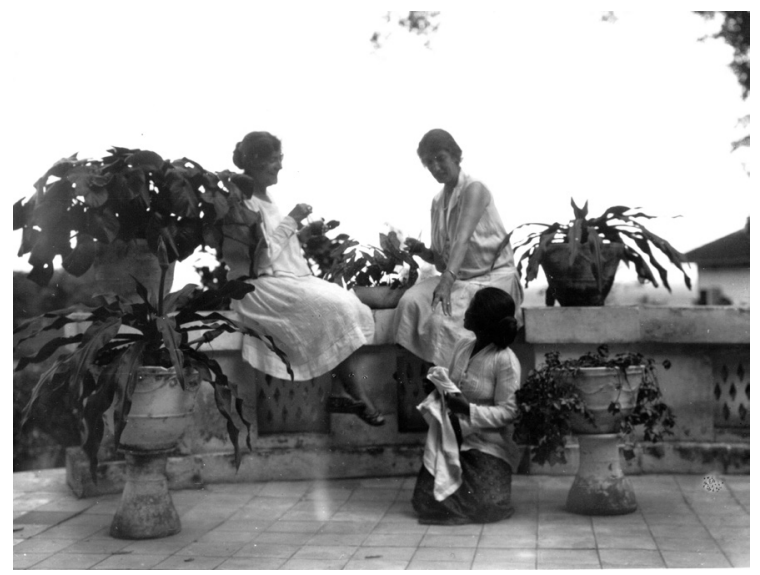

Fig. 10. Johanna Bezoet de Bie and a friend seated on a balustrade, with Indonesian servant squatting. horse-drawn barouche or open carriage, complete with Javanese coachman, while another records two European women - one them Johanna Bezoet de Bie herself - seated on a balustrade with an Indonesian $b a b u$ squatting quite literally at their feet; while others are less concerned with colonial 'subjects' per se than with the suggestion of 'exotic' situations and circumstance far removed from those of the metropole - and in this sense, very much of their time ${ }^{41}$ Generally speaking, for example, monkeys do no disport themselves around the tea tables on the lawns of the Haagse bourgeoisie, as they do in one of the photographs that MacNeill and Bezoet de Bie sent back to the Netherlands to delight their relatives.

Yet images of this kind are few and far between. Instead, what emerges from the generality of the photographic 'archive' is something rather different: an environment that had little or no significant reference to Indonesia's 'native' inhabitants and, in the context of colonial settlement, an attenuated sense of belonging to the Old Indies World. Identity in such circumstances was, of course, multidimensional and the family's situation was not without its

have relied heavily for the influence which he was able to exert in the surrounding countryside. Together with his wife, the raden ajoe, their child and an accompanying younger man, identified as a mantri or administrative assistant, all four of them are posed in front of what may have been the wedono's 'audience hall' or pendopo. Clearly, he and his wife were not part of the Oemboel social circle.

41. Junge, 'Groet uit Java': 171. 


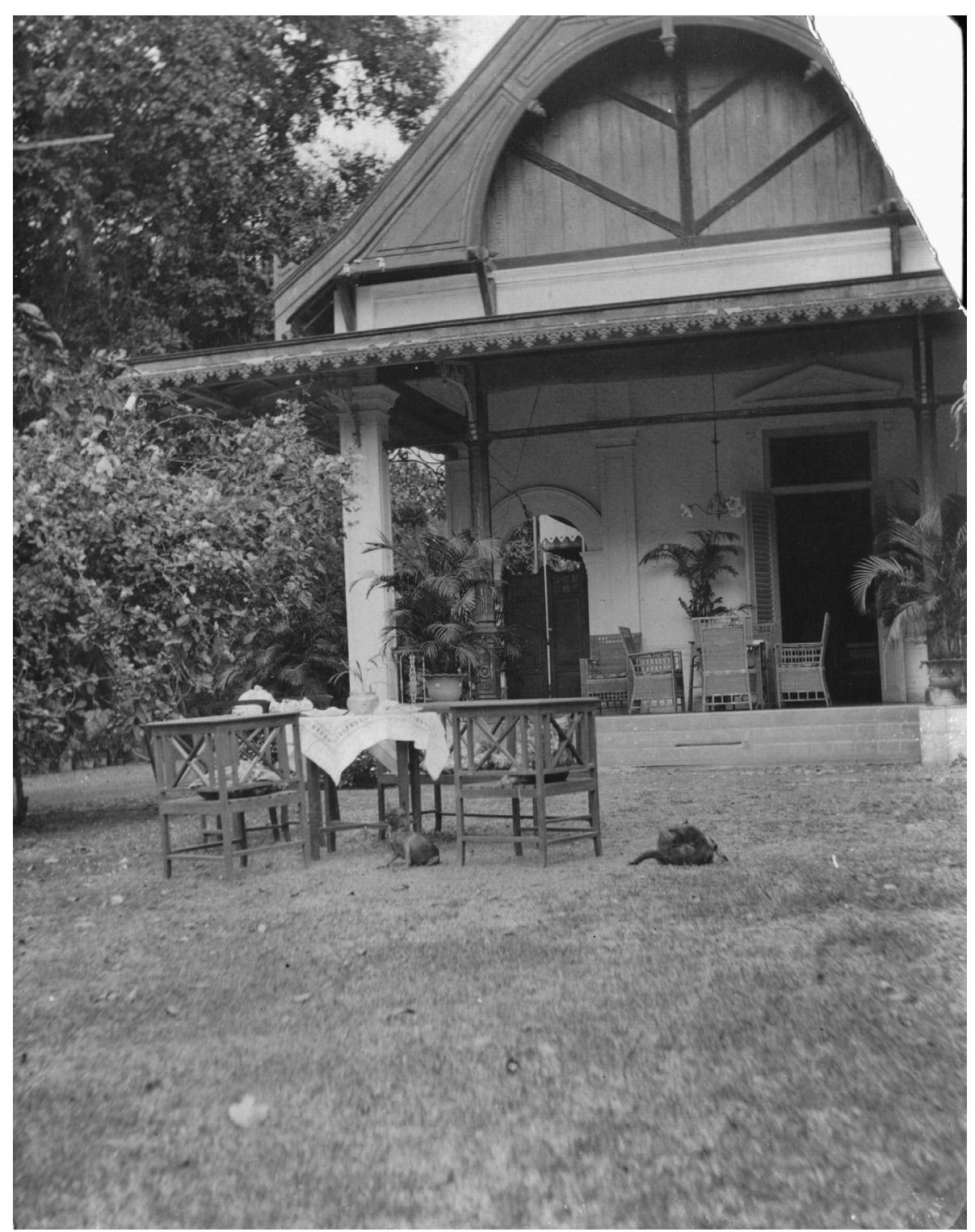

Fig. 11. Monkeys on the lawn. 
ambiguities and complexities. Nonetheless, there remains a distinct sense of the extent to which they sought to build identities in which the dominant motif was at some remove from the locality into which they had both been born.

Photographs of the interior of the MacNeill's house at Oemboel are arguably revealing in this respect. The predominant effect is to convey - and was surely meant to convey - the way in which the spaciousness and luxe of the interiors enjoyed by the bourgeoisie in the West could be replicated in even as 'remote' an 'outpost' as Probolinggo. There was a (covered) piano with a music stand next to it and other rich furnishings included paintings in ornate frames as well as on easels, carpets on tables and floors, a plethora of jardinières with potted palms, what appear to be gasoliers (perhaps the gas manufactured to light the factory for its 24-hour operation during the campaign was also piped into the administrateur's house) and other ornate lamps, and a table set for dinner. That dinner, of course, might have revolved around the famed rijsttafel, an Indisch meal based on the offering of a multiplicity of miscellaneous side-dishes - European as well as 'Asian' - served on a bed of rice, but there is no visual reference to it, nor to the small bevy of household staff required for its service. Canned and otherwise preserved food imported from Europe had not yet become - as it did in the inter-war decades - de rigueur for socially elevated creoles like the MacNeills. ${ }^{42}$ Figuratively speaking, however, the table was already set for its arrival.

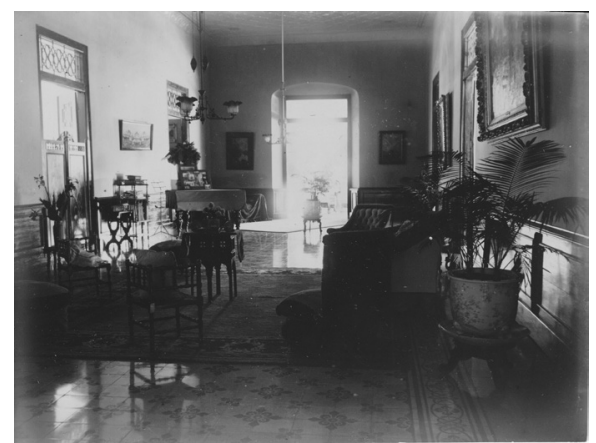

Fig. 12. Interior of administrateur's house at Oemboel. Note the piano and music stand in the background.

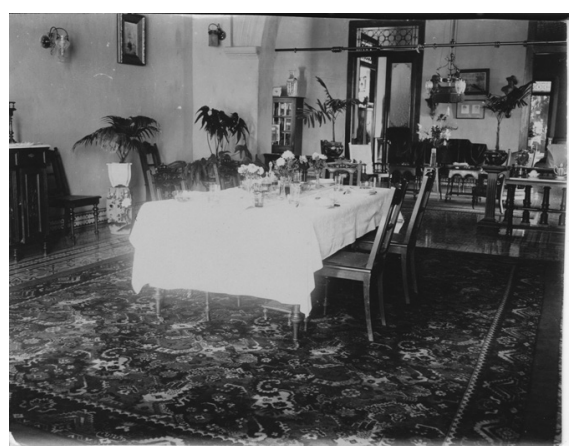

Fig. 13. Oemboel interior.

Identity, of course, was manifest not just in the way a house might be furnished or in what the household consumed at meal times, but also in outward appearances. One informal portrait of Johanna Bezoet de Bie present in the archive shows her seated, reading a newspaper or possibly a magazine - and clad in the 'traditional' informal female attire of colonial Java, the

42. Susie Protschky, 'The Colonial Table: Food, Culture and Dutch Identity in Colonial Indonesia', in Australian Journal of Politics and History, 54, 3 (2008): 346-357. 


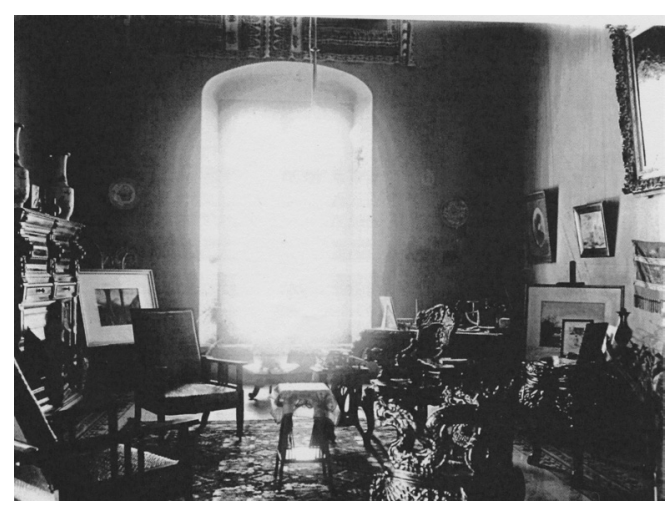

Fig. 14. Oemboel interior.

sarong and kebaya - a longsleeved lace jacket worn over a length of batiked cotton folded around the body like a skirt. Of Javanese inspiration, it would have looked exotic indeed to those unacquainted with the Indies. Indeed, one (rare) North American visitor to Java in the late nineteenth century had professed herself shocked at the daytime state of undress of the colonial women she saw in her hotel. $^{43}$

As its foremost historian has noted, however, from the opening of the twentieth century onward, what a colonial woman might wear in the home was in state of flux, within the context of a discourse, still by no means uncontested in the early years of the century, about the danger of 'going native' and the resultant urge for 'modernisation', not least in matters of women's clothing. Eventually, this meant that, by the inter-war decades, Western-style summer dresses had relegated sarong and kebaya to the old-fashioned, to the backwoods and to the lower orders among Indies' colonial communities. ${ }^{44}$

The MacNeill couple, it may safely be assumed, wanted to make it quite clear that they were not located among any such 'backwoods' (or, of course, among creole subalterns). Hence the potential significance what Bezoet de Bie and her female companions are wearing in another photograph, in this instance of a small daytime gathering - presumably at Oemboel and probably sometime just after the turn of the century.

Whatever the precise occasion, it was evidently an informal one: seven women and four men are on the back patio, mostly on rocking chairs that the (invisible) servants would no doubt have carried from inside the house. An event of some kind is being toasted with what looks like champagne cups filled with drink from the tureen that sits on the table; two individuals appear to have left their chairs at the back of the group and are positioned on the edge of the veranda, the better to be included in the picture; another chair is empty, presumably the seat of the person - most likely Alexander MacNeill himself -

43. Eliza Ruhamah Scidmore, Java: The Garden of the East, 1897 [reprinted New York: Century, 1907]: 25-6.

44. Elsbeth Locher-Scholten, 'Summer Dresses and Canned Food: European Women and Western Lifestyles', in Locher-Scholten, Women and the Colonial State, Amsterdam, Amsterdam University Press, 2000: 120-131. 


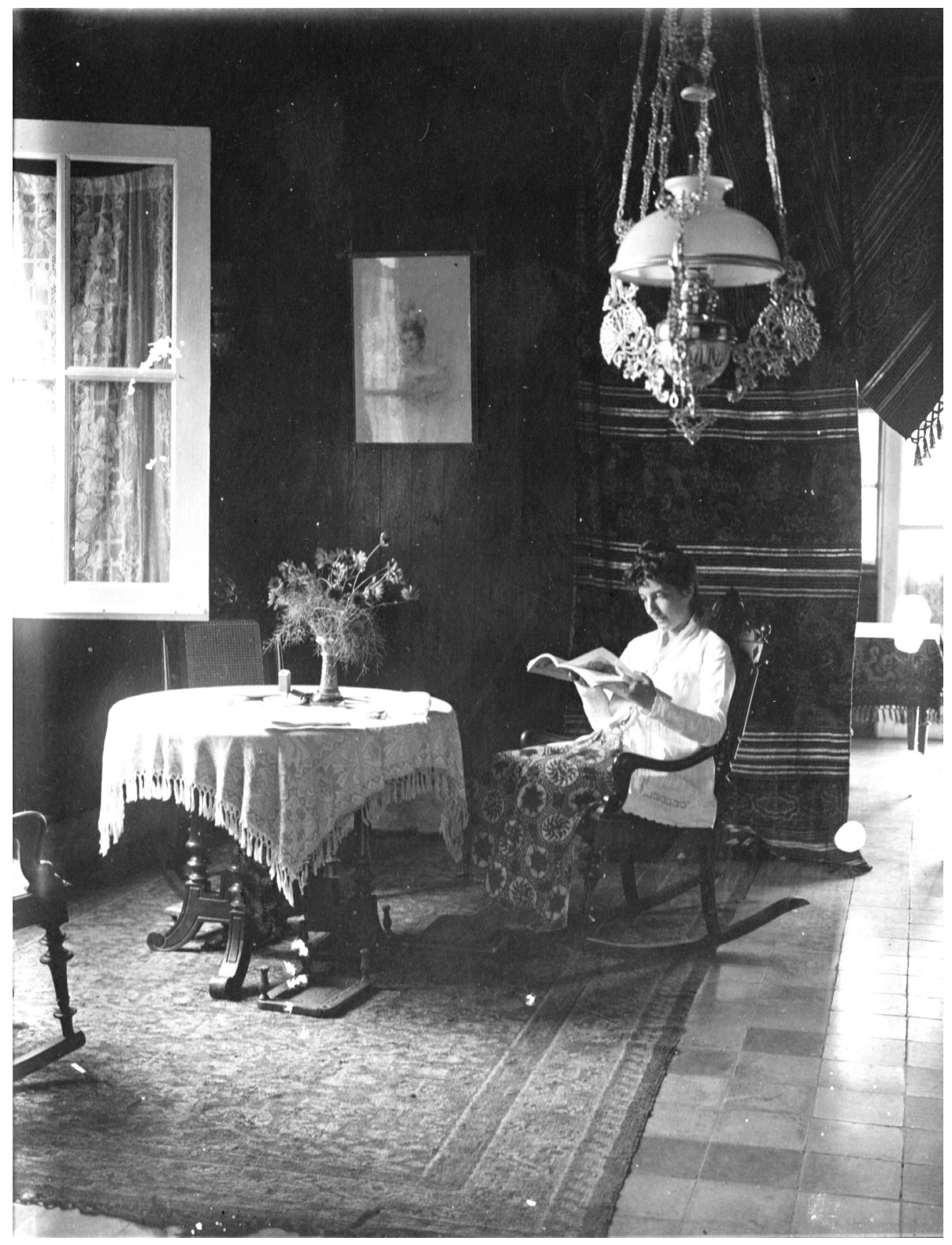

Fig. 15. Bezoet De Bie in sarong and kebaya, reading a magazine. 


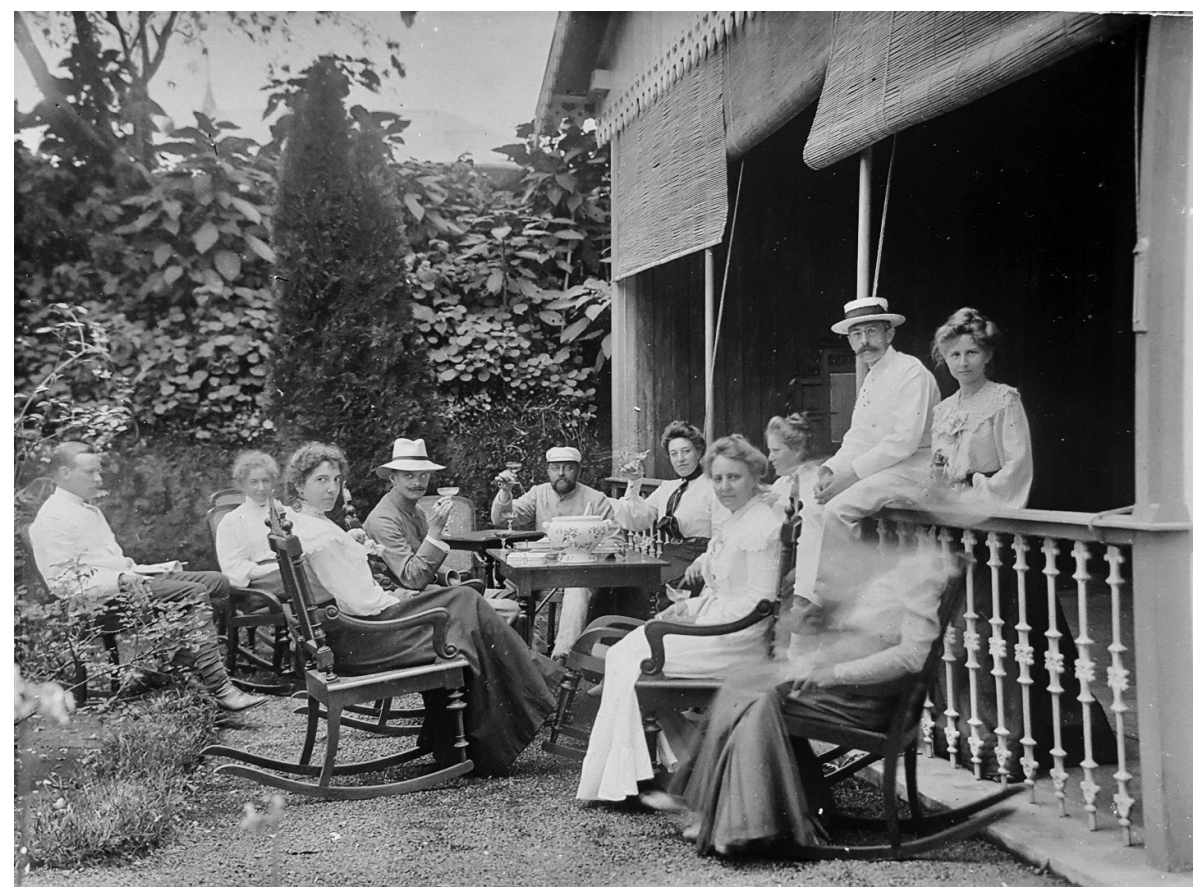

Fig. 16. Party Scene with friends.

who is behind the camera. As if to confirm a family event caught on the wing, one of the women appears to have rocked on her chair (?) during the second of exposure - and is hence lost to posterity. Not so Bezoet-de-Bie herself, however, whose presence is unmistakeable (third from the left). Of sarong and kebaya, there is no sign: what has taken its place is a pairing of a long-sleeved cotton blouse (the lace has gone) with a long ankle-length skirt of heavyish material and of European design. It is a costume that would scarcely been out of place among their contemporaries in The Hague.

In the case of the MacNeill couple, however, the celebration of family life also partook of a quite formal character, as befitted their exalted station in the community, in the shape of photographs made in the prestigious surroundings of the Kurkdjian studio in Surabaya. Ohannes Kurkdjian (1851 - 1903), an Armenian émigré who had arrived in Java in 1886, had an international reputation. Any work done in his atelier, which employed up to thirty-five staff and, among others, nurtured colonial Indonesia's first female professional photographer, Thilly Weissenborn (1883-1964), and long survived Kurkdjian's own demise, would have come at a premium price. ${ }^{45}$

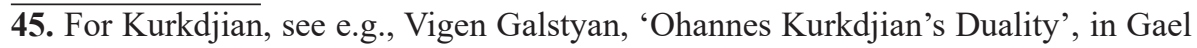


Ironically enough, given that the studio itself was most famed for its depictions of Javanese landscapes, the MacNeill photographs are so totally divorced from any obviously Indonesian context that they could just as well have been made in the Netherlands. Such photos were, no doubt, the outcome of regular trips from a provincial town to the East Java metropolis that were integral to the life-style of a well-to-do sugar factory administrateur - but arguably also reflect something of the couple's determination, conscious or otherwise, to present themselves and their offspring in a European frame, in which their hybrid identities were deliberately downplayed.

\section{Connecting to 'Home': An English Governess}

Cornelia Vissering's brief encounter with Johanna Bezoet de Bie and her two young sons (her baby daughter had presumably been put to bed prior to the arrival of the evening visitor) up in the Tengger mountains in 1907 made mention (as we have already seen) of the presence of the family's 'slender blond' [tengere blonde] English governess. ${ }^{46}$ If the MacNeill couple were indeed concerned to present themselves in a frame more redolent of Europe itself than of the Indies, then the education of their children was a perhaps crucial pointer. It was thoroughly in character for Java's creole families to send their offspring, the boys in particular, for schooling in the Netherlands once they approached their teens. Evidently, however, MacNeill and Bezoet de Bie also took care of their children's pre-teen upbringing by employing a governess. Moreover, presumably in order to preserve the family's British (Scots) heritage, they employed for the purpose a woman born in the UK rather than in the Netherlands. The woman in question can be identified as the thirty-seven year old Eugenie Jackson (b.1867). The daughter of a prosperous shopkeeper from the Thames valley town of Maidenhead, prior to joining the MacNeill-Bezoet de Bie family, she had been employed as a children's nurse (the Dutch term was kinderjuffrouw and it was used in her application to the colonial authorities in Java for a residence permit) in the well-to-do household of the Town Clerk of Croydon, in the Surry suburbs immediately to the south of London. ${ }^{47}$ It is not clear how she subsequently came to be employed by the MacNeills, but what is certain is that she accompanied them to the Indies when they sailed back to Java in March 1904 (after an eight month sojourn in The Hague $)^{48}$ - and that she remained in their service for the next seven years. There are at least two photographs in which she is identified: the first

Newton (ed.), Garden of the East. Photography in Indonesia 1850s-1940s, Canberra, National Gallery of Australia, 2014: 70-73; private communication 10.5.2018, Dr. Alexander Supartono, Edinburgh Napier University.

46. Vissering, Oost-Java: 178.

47. NA, Oost-Indische Besluiten, 2.10.30, no. 8377, 1906; Census UK 1871 and Census UK 1901 [from Ancestry.com].

48. Bataviasche Nieuwsblad [hereafter BN] 13.7.1903 \& 05.04.1904. 


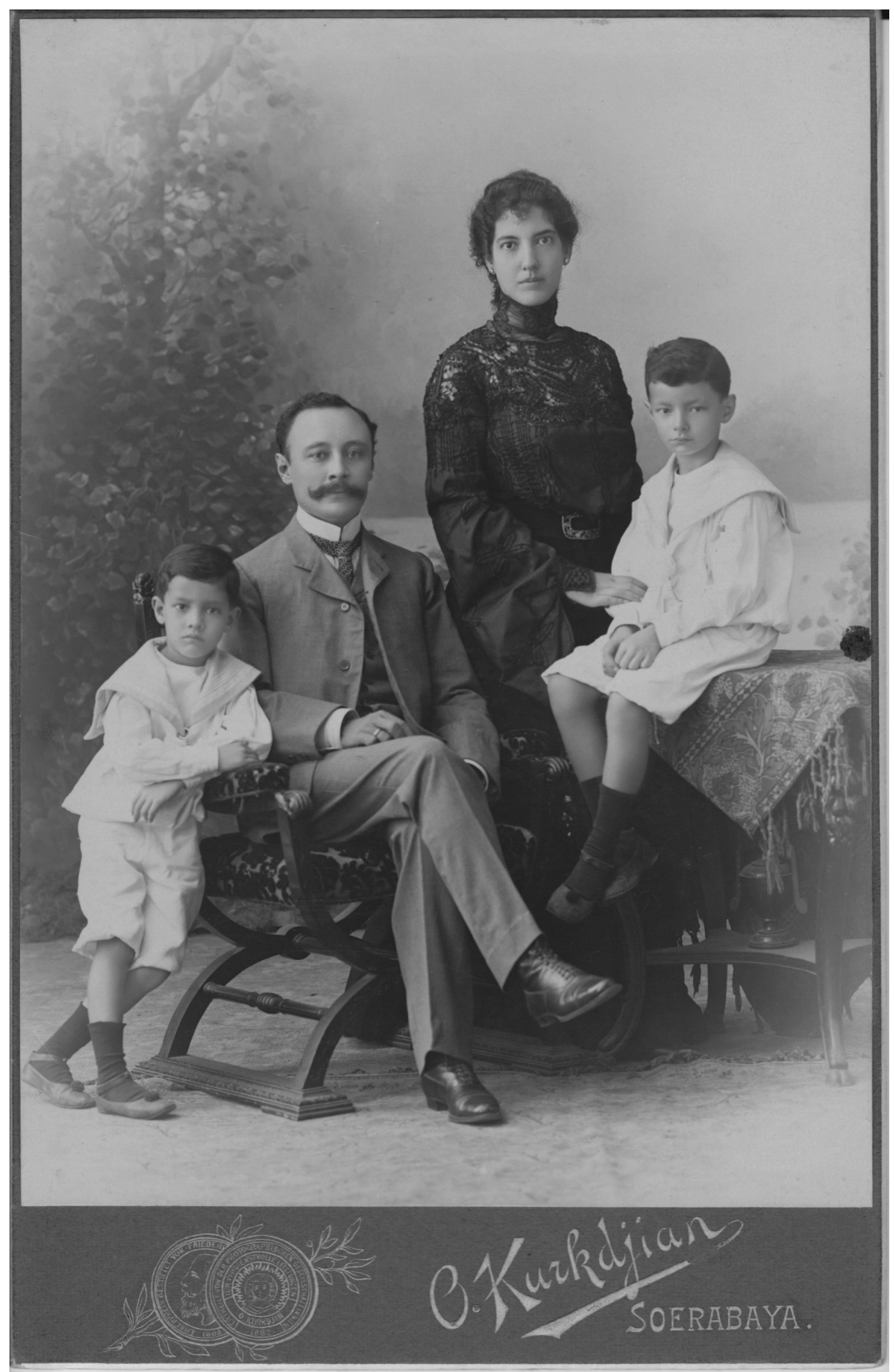

Fig. 17. Kurkdjian studio photo of Bezoet De Bie, MacNeill and children c. 1905. 


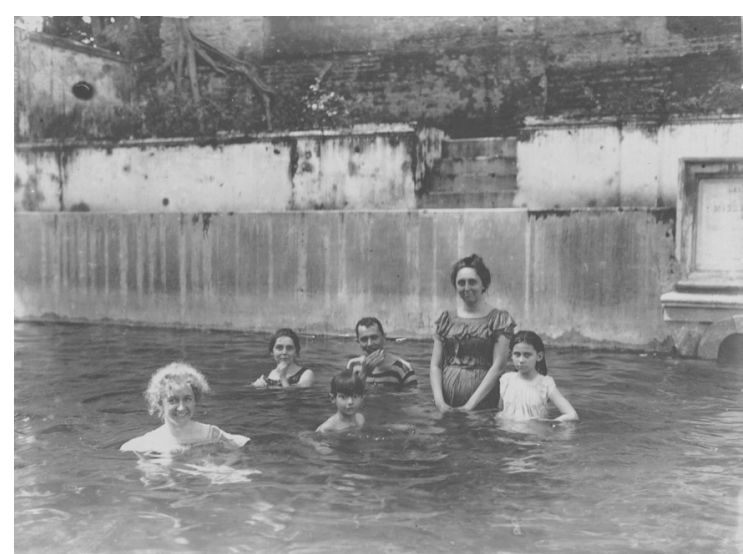

Fig. 18. Eugenia Jackson (left) in the swimming pool at Oemboel. shows her in the swimming pool at Oemboel and the second sitting with the mistress of the house and the couple's two sons, in company with a pair of house guests. The social position of the governess in many metropolitan colonial households was often ambiguous: at Oemboel, however, there appears no doubt that she was 'one of the family'.

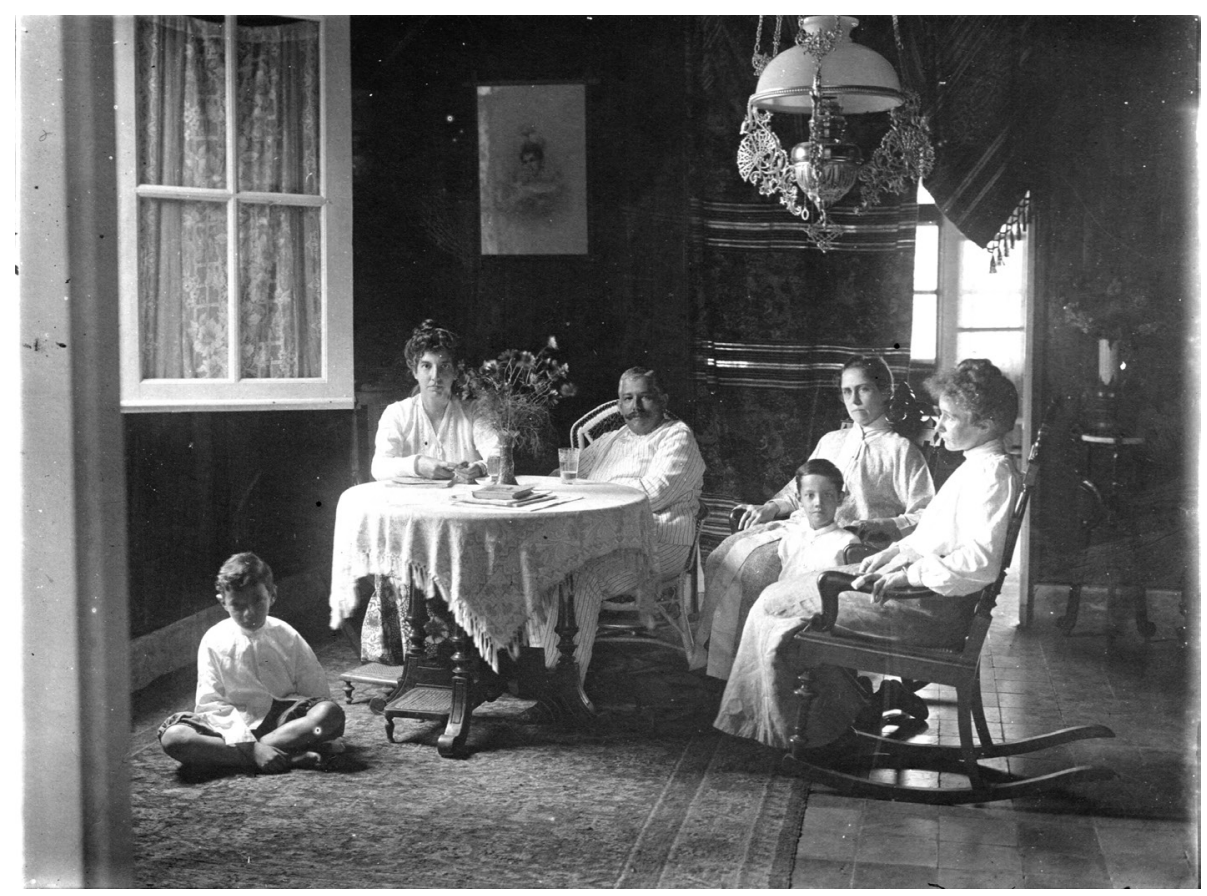

Fig. 19. Eugenia Jackson at the breakfast table (right) with Bezoet De Bie, her two sons and unidentified visitors (MacNeill is absent from the photograph). 
In the year following her arrival, Jackson accompanied the family to the fashionable Tosari Hotel-and-Sanitorium complex high in the Tengger mountains ${ }^{49}$ - at nearly 1,800 metres, it advertised itself as having a 'European' climate - and stayed there for around a month at the end of sugar campaign in $1905 .^{50}$ Vissering herself went there a couple of years later toward the close of her tour of East Java, and commented, not altogether favourably, on its wealthy clientele of elite families from Surabaya, sugar factory managers and the like..$^{51}$ In MacNeill's case, however, it may have been less a social occasion than a necessary restorative for his health after the rigours of managing the year's campaign. Jackson subsequently sailed together with the family when they made another voyage to the Netherlands late in 1908,52 a journey perhaps designed to show off the couple's recently born daughter, Alexandra MacNeill (1907-1981) to their relatives in The Hague - and certainly to deposit their two boys, Richard MacNeill Jnr (1898- 1963) and John Alexander MacNeill (1899- 1979), to continue their education 'in patria': the elder boy was subsequently enrolled (1916) in the Nederlandsche Handels- Hoogeschool in Rotterdam. ${ }^{53}$ Late in 1909 their parents went back to Java with Jackson and their daughter ${ }^{54}$ but returned to the Netherlands some two years later toward the close of 1911. This time, however, Jackson did not accompany them on the voyage and instead appears to have remained at Oemboel, presumably as governess to successive managerial families at the factory until the close of the 1920s, at which point she disappeared from the public record. ${ }^{55}$

Governesses were, of course, a fixture of metropolitan and colonial life for middle and upper class Europeans throughout the 'long' nineteenth century, and for single women such positions afforded the possibility of 'genteel' employment commensurate with either their actual or perceived social standing. In case of the United Kingdom, by the late nineteenth century significant numbers not only of 'impoverished gentlewomen' but also their counterparts in the lower middle classes hoped to find employment not only within Britain and its Empire but also in other parts of the world that placed a premium on a command of the English language. ${ }^{56}$ They might even be seen as

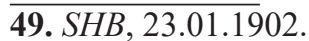

50. $S H B, 21.10 .1905 \& 18.11 .1905$.

51. Vissering, Oost-Java: 203-215.

52. SHB, 31.10.1908.

53. H.C. de Roo-Schouman, 'Album Studiosorum Roterodanum 1913-1953', Indische Navorscher 9 (1996): 122.

54. $B N, 09.11 .1909$.

55. Nieuw Adresboek van Geheel Nederlandsch-Indië, Batavia, Landsdrukkerij, 1903-1930.

56. A. James Hammerton, Emigrant Gentlewomen. Genteel Poverty and Female Emigration, 1830-1914, London, Croom Helm, 1979: 148-186; Kathryn Hughes, The Victorian Governess, London, The Hamledon Press: xv-xvi. 
'missionaries', possessed, as one contemporary propagandist expressed it, of 'a splendid opportunity of serving the Empire by instilling British principles into the minds of the children'. ${ }^{57}$

In the case of the MacNeill family - and somewhat more mundanely - a British governess would have provided an opportunity for perpetuating the links with a 'home' that was in the UK as well as in the Netherlands. It did so, moreover, at a delicate time for British loyalties in a Dutch colony, given the ill feeling in the Netherlands - as well as in the Indies - about the treatment of Dutch communities in southern Africa during the only recently terminated Boer War. ${ }^{58}$ In terms of 'identity', that is to say, the import of the couple's employment of Miss Jackson meant that their offspring would be conversant with English as well as Dutch (in addition to the Javanese that they would have learnt from their $b a b u$ ). But is it too fanciful to see it as also implying that that couple were aiming to locate their offspring in a similar cultural milieu to that of their British cousins, members of the (legitimate) branch of the family that patriarch Alexander MacNeill Snr had established in the UK after his return there at the end of the 1840 s? ${ }^{59}$

\section{A Sojourn In 'Patria': The Hague 1911-1928}

'These people led interstitial lives', one recent student of the Indies colonial elite has remarked, and 'were always in some kind of transition.' ${ }^{60}$ Up to a point, this was indeed the case with the McNeill-Bezoet de Bie couple, whose repeated voyaging between Asia and Europe was characteristic of the Indies colonial elite in general. ${ }^{61}$ Their lives entered a new phase late in 1911, however, when the husband retired from his position as administrateur at Oemboel, and the couple left Java for the Netherlands. They sailed to Europe in company - on the upper deck, of course - with several other sugar factory administrateurs who were evidently taking advantage of the end of the sugar campaign to take a vacation. ${ }^{62}$ For the MacNeills, however, this was no vacation but an ostensibly permanent relocation in 'patria' that saw them settled by

57. Hammerton, Emigrant Gentlewomen: 165.

58. Heather Street-Salter, World War One in Southeast Asia, Cambridge, Cambridge University Press, 2017: 95.

59. Several of those cousins were present in Java, working for the Maclaine Watson Concern, contemporaneously with Alexander and Johanna MacNeill's sojourn at Oemboel between 1898 and 1911. What is unknown, however, is what kind of contact the two branches had - if, indeed, they had any contact at all.

60. Caroline Drieenhuizen, 'Objects, Nostalgia and the Dutch Colonial Elite in Times of Transition ca. 1900-1970', Bijdragen tot de Taal-, Land-en Volkenkunde, 170 (2014): 509.

61. Ulbe Bosma, 'Sailing through Suez from the South. The Emergence of an IndiesDutch Migration Circuit, 1815-1940', International Migration Review 41/2 (2007): 511-36.

62. Nieuws van den Dag, 25.10.1911. 
January of the following year in a house on the Statenlaan, ${ }^{63}$ in a relatively new elite district of The Hague, within walking distance of Alexander's father's mansion on the Koninginnegracht, the canal-side boulevard that connected the city centre to the seaside resort of Scheveningen. The family was to remain in The Hague, at various addresses, until the late 1920s.

Once established there, among other things, they appear to have gravitated toward the city's renowned artistic circles - circles that were at some remove, it might be supposed, from those conventionally associated with the retired administrateur of a sugar factory and his nyonya besar. MacNeill himself may well have had some aspirations as a painter (as stories passed down in the family would have it), and the couple evidently became associated (though documentation is slender) with the dominant figure among Hague-based artists, the painter Floris Arntzenius (1864-1925). Arntzenius did portraits still extant - of both MacNeill and Bezoet de Bie.
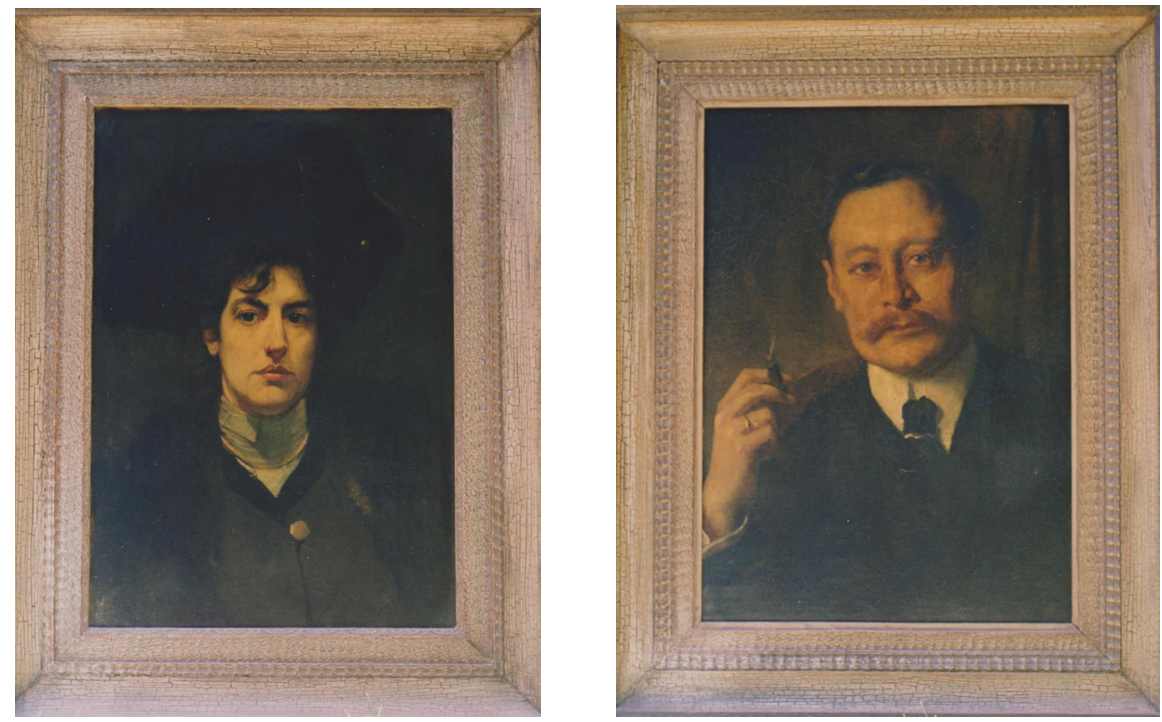

Fig. 20 \& 21. Portraits by Arntzenius of Johanna Bezoet De Bie and Alexander Macneill.

More revealing of the social links between the MacNeills and Arntzenius, which obviously extended beyond their patronage of a famous artist, was the fact that one of the latter's daughters, Claudine Albertine Arntzenius (19041982) - younger sister of the celebrated painter, ceramicist and photographer Elise Claudine Arntzenius (1902-1982) - married MacNeill's nephew Wilhelm van der Weijde (1896-1957) at the beginning of the 1930s. To be sure, these

63. Haags Gemeente Archief, Den Haag, Bevolkingsregisters, Burgerlijke Stand 1895-1913 [via Open Archief]. 
pre-occupations did not mean a complete break with the Indies, since the painter himself was also of Indies birth, and counted many similarly Indiesborn individuals among his artistic associates in the Netherlands. ${ }^{64}$ Moreover, simply living in The Hague in the opening decades of the twentieth century meant being immersed in a society at all levels of which the Indies was a pervasive presence. ${ }^{65}$ Even so, Arntzenius had been taken from his native Surabaya to the Netherlands as a boy of eleven, and never returned there. Nor, it might be supposed, did the MacNeill couple intend to do so after there own relocation to the Netherlands.

It can be assumed that part of the purpose in leaving Oemboel had been to re-unite in the Netherlands with their sons - and with their own, aging parents. Richard MacNeill, founder of the Dutch branch of the family, died in The Hague in 1915, within a very few months of the death of Johanna MacNeill's own father, Herman Bezoet de Bie. His widow, Sarah Sijthof-Bezoet de Bie (1849-1934) however, survived her husband by almost two decades, and lived in The Hague only a few streets away from her daughter, as did other members of the extensive Bezoet de Bie family. It may have been around this time that Bezoet de Bie herself (as a report handed down in the family has it) developed an interest in the Christian Science movement, whose church in the Hague, built during her sojourn there by the eminent, pioneering modernist architect and artist H. P. Berlage (1856- 1934) - famous, above all, for his Bourse building on Amsterdam's Damrak and, in the penultimate stage of his career, for the Gemeentemuseum (Municipal Museum) in The Hague itself - was a testimony not only to the congregation's advanced taste but also to the depth of its pockets. ${ }^{66}$

Her offspring, meanwhile, ostensibly at least, adapted to their adopted country by marrying into solidly Dutch bourgeois families who were devoid of any direct Indies connections. Richard (aka Dick) MacNeill Jnr, the elder of the couple's two sons and a world-class footballer during his younger years in the Netherlands, married a keen sportswoman, Alide Schoute (1901-1952), the hockey-playing daughter of a well-known Dutch cocoa and chocolate manufacturer and his likewise Netherlands-born wife. ${ }^{67}$ Dick MacNeill went on to forge a career in banking, living in the elite 'dormitory' town of Heemstede and working in Amsterdam - a short train ride away - for the prominent firm

64. Dolf Welling, Floris Arntzenius, Den Haag, Heemhave Holding BV/ Van Voorst van Beest Gallerie, 1992:16.

65. E.g., van Doorn, Het leven gaat er een lichten gang: 39-66.

66. She was not, however, formally a member of the congregation in The Hague (I am grateful on this point for information kindly supplied by email by Mijnheer Wally Eman, Church of Christian Science in the Netherlands, 29.7.18).

67. Except where stated, the information in this and the following paragraphs comes from the late Dirk MacNeill's extensive type-written notes on his father and uncles and grandmother. Copies in the possession of Mevrouw Elizabeth del Court Konig van Essen, The Hague. 
of Albert de Barry \& Co. By the 1930s, with offices on the prestigious 'golden bend' in the city's Herengracht, De Barry was almost entirely German-owned and closely connected with the Deutsche Bank, one of the financial pillars of the Third Reich. As such, its assets were confiscated post-Liberation in May 1945, a move that may also have cost Richard MacNeill his job. ${ }^{68}$ In any event, after the War he relocated to Antwerp, where he found employment as a bank manager, but the onset of what proved to be his wife's fatal illness brought the couple back to the Netherlands, where she died in 1952. Her widower subsequently remarried - and acquired two step-children - but himself died suddenly in Heemstede in 1963, in his substantial semi-detached house in an elite part of the town, aged scarcely sixty-five.

Meanwhile, his younger brother, John Alexander MacNeill, also pursued a Netherlands-based business career in finance, as secretary to a mortgage company and - like his siblings - married into metropolitan business circles. At the same time, the extent to which he was embedded in Dutch society was underscored by the fact that at an earlier stage in his career, in the mid-1920s, he had been an officer in the Koninklijke Landmacht (the Royal Dutch Army), and evidently kept up his connections with its officer corps after he had returned to civilian life. ${ }^{69}$ His wife, Johanna Augusta Eugenia Josephina de Poorter (1903-1997), whom he married in The Hague in 1927, was the daughter of a man whose career had been in commerce [handelsagent/ koopman], while her mother, Elisabeth Anna Berlage, came from an Amsterdam (originally German) mercantile family. Though MacNeill himself appears to have spent some time across the Atlantic - in New York - in the period immediately before his marriage, thereafter the couple spent their entire lives in The Hague, where they had a house on the Frederik Hendriklaan, in the heart of the middle class Statenkwatier, between the city centre and the sea.

The third and last of Alexander and Johanna MacNeill's offspring to wed was their only daughter, the twenty year old, Java-born, Alexandra Wilhelmina Johanna MacNeill (1907-1981). The marriage took place in The Hague early in 1928 and her husband, Johannes de Crane (1903-1968), four years her senior and born in the Netherlands, worked in insurance (as had his father), where he was employed for much of his life by the prominent Amsterdam-based firm of Blom \& Van der Aa. Although the firm did considerable business in the Indies and China prior to the Second World War, De Crane and his wife remained living in the Low Countries, in Antwerp, Rotterdam and Amsterdam.

\footnotetext{
68. Founded 1919, the Bank had, from its inception, strong ties with German banking circles, and, subsequently, with Deutsche Bank in Berlin (which held $90 \%$ of its shares by the 1930s). Confiscated as a German asset by the Dutch Government in 1945, De Barry's German connection endured when De Barry was returned to private hands in 1954. See 'Geschiedenis van H. Albert de Barry en de Deutsche Bank', in www. amsterdamsegrachtenhuizen.info/grachten/hge/.../hg18448/?. Accessed 30-3-18.
}

69. Haagse Courant, 17.11.1937; NA 2.13.05/2.13.04, Collectie Officieren Landmacht Nederland: Stamboekregistraties 1813-1924. 


\section{The Inescapable Indies: Credentials and Cash}

Nonetheless, despite the extent of the MacNeill's domestication in the Netherlands, the Indies proved reluctant to let go of its own. Hence when Dick MacNeill, the football-playing, internationally renowned young sportsman of the family, proved particularly valiant in defence of his metropolitan team's goal, he was hailed in the colonial press as one of their own - 'an Indischman by the name of Mac Neil' ${ }^{70}$ For his parents, moreover, the Indies proved quite literally inescapable. If the couple, as seems probable, had intentions of spending the rest of their lives in the Netherlands, in company with their children and grandchildren, then they were disappointed. While living in The Hague, they must have drawn on their savings and on whatever share they had in the Wonolangan Plantation Company and kindred enterprises that MacNeill's father had been the prime force in establishing late in the preceding century. Early in the 1920s, moreover, Alexander MacNeill himself had parlayed his lengthy experience in the sugar industry into a job of sorts in promoting the sale in Java of a well-known British manufacturer's diesel-engine ploughs for work in the island's sugar fields. Indeed, it was this that took him to the Indies on at least a couple of occasions prior to his final relocation there later in the decade. ${ }^{71}$ The times were against the success of the venture, however, not least because from the mid-1920s onward cheap labour began to pour into the Java sugar industry on a scale that had not been known for decades, largely obviating the need to mechanise fieldwork. ${ }^{72}$

This seems likely to have left the couple in straitened financial circumstances, with the upshot that, in April 1928, once all three of their children were married and 'off their hands', MacNeill and Bezoet de Bie sailed back to the Indies. Some eighteen months later, at the close of 1929, the Wall Street Crash - and subsequent onset of Inter-War Depression - must have confirmed the wisdom of their choice. Inter alia, it brought about the near-collapse of the Java sugar industry on which so many Dutch families (like theirs) had come to depend for an income, and created a situation in which numbers of ex-colonials returned to the Indies, since they calculated it was much cheaper to live there than in the Netherlands in their reduced financial circumstances. By then, however, MacNeill and Bezoet de Bie themselves had already been settled back in their native country for a couple of years or more.

$\overline{\text { 70. Sumatra Post, }}$ 03.06.1920.

71. A. MacNeill, 'Mechanische grondbewerking met den Kabelploeg der firma John Fowler \& Co., met illust. 'Archief voor de Suikerindustrie NI, 1923, 1: 343-67. The Leeds (UK) firm of John Fowler \& Co were leading British manufacturers of traction engines and ploughing implements and equipment. See: https://en.wikipedia.org/ wiki/John_Fowler \%26_Co. Accessed 14-6-18.

72. E.g., Roger Wiseman, 'Three crises: management in the colonial Java sugar industry 1880s-1930s', PhD Dissertation, University of Adelaide, 2001: 431-2 (available at http://hdl.handle.net/2440/21822). 
Instead of returning to their old location in the Oosthoek, the couple had opted to settle on the edge of the mountains of Central Java, at Bandungan in the neighbourhood of the town and military cantonment of Ambarawa, some forty kilometres south of the port-city of Semarang where MacNeill's Scots grandfather - also Alexander MacNeill - had started out in business almost a century earlier. Literally and metaphorically, they were at some considerable distance from their former life at Probolinggo, more than 400 kilometres away to the east, and set about forging a new and different colonial identity, one in which Johanna Bezoet de Bie-MacNeill was much to the fore.

Her previous colonial persona as the nyonya besar of a sugar factory's general manager would not have left her idle: quite the contrary, since her likely position as the family's (chief) letter writer - her husband being largely consumed by the business of the fabriek - would have placed her at the centre of the communications network that linked the Indies colonial elite to its metropolitan counterpart, while at the same time maintaining the vital web of ties between 'family' in the colony itself. ${ }^{73}$ Her new role, however, as the marital partner of an ailing retiree - Alexander MacNeill died in March 1937 within a decade of the couple's return to the colony - was no longer a 'behind the scenes' one. Instead, she became the driving force in small venture that produced strawberries and other cool climate crops for sale to the resort hotels in Ambarawa as well as in Semarang itself. The photographic 'archive' - as well as stories handed down in the family about a woman who lived into the $1950 \mathrm{~s}$ - is revealing here. The couple's residence was evidently a modest one in comparison with what they had known at Oemboel, and one of the few photographs of its interior (a photograph to which the passage of time has not been kind) shows a corner, more gezellig (cosy) than grand, and has written on the back the revealing remark (dated 13.4.1936) that this was " the nicest part of the house'.

The most rewarding of the contemporary photos, however, show Bezoet de Bie-MacNeill in her market garden, accompanied by a small group of other European women in various poses - but dressed in a fashion that makes it clear that they are not involved, of course, in field work. As before, Indonesians - the people who would actually have planted and tended the crops - are themselves absent from the scene.

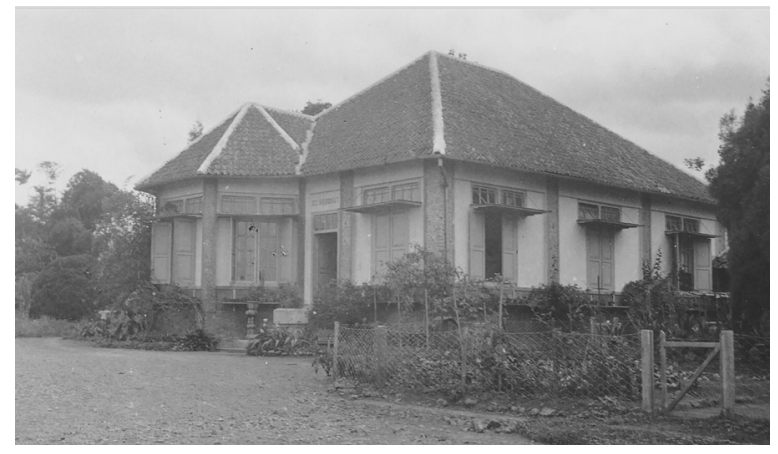

Fig. 22. 1930s: The Couple's House at Bandungan, Central Java.

73. See, e.g., Henk Schulte Nordholt (ed.), Het dagelijks leven in Indië 1937-1947: brieven van O. Schulte Nordholt-Zielhuis, Zutphen, Walburg Pers, 1999: 9-11. 


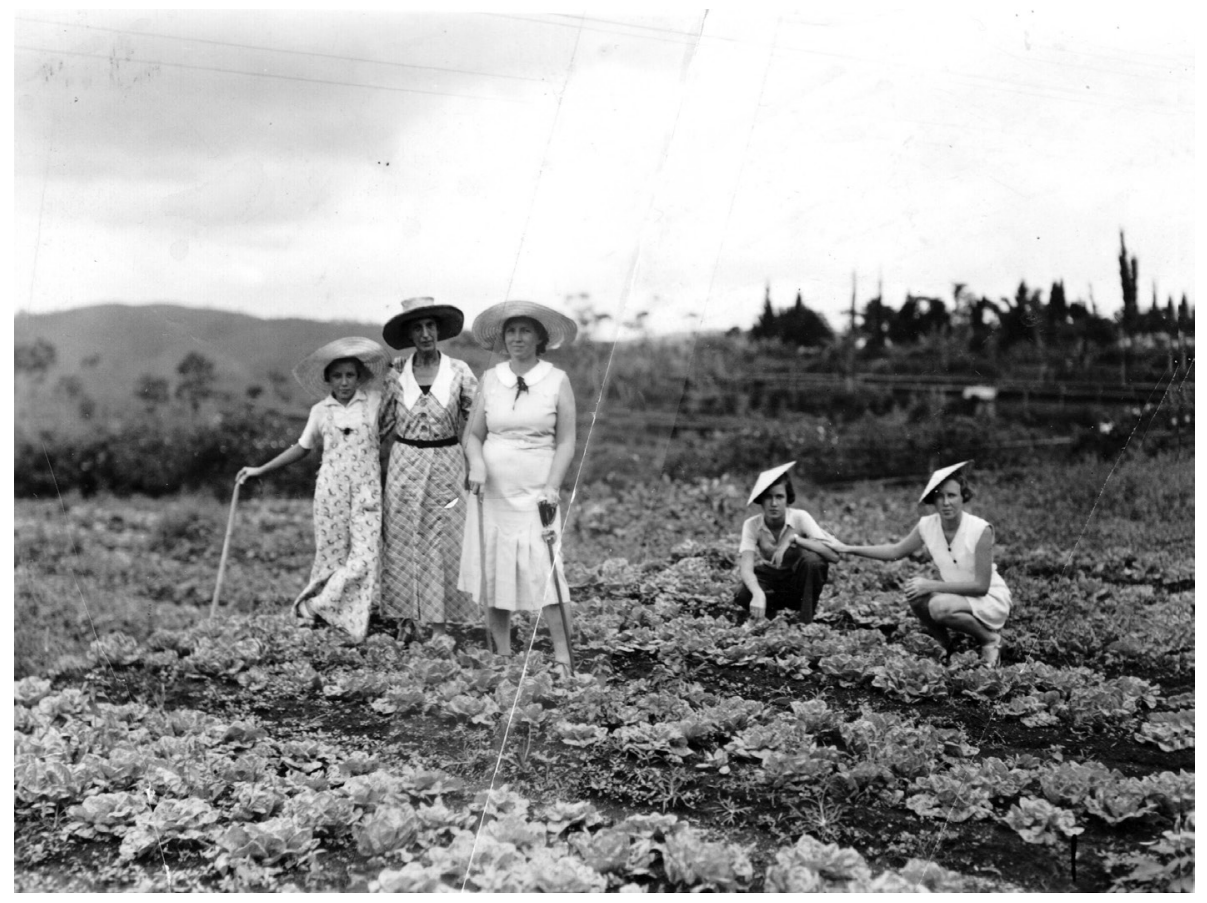

Fig. 23. 1930s: Johanna Bezoet De Bie and friends in her market garden.

After her husband's death, Johanna Bezoet de Bie did not remain long in the Indies. Indeed, she sailed back to the Netherlands two months later, in May $1937,{ }^{74}$ and was re-united there with both sides of her family. It may well have been a happy return: leastways, a year or two later, sometime toward the end of the 1930s, a street photographer, poised with his camera in the centre of The Hague, near the medieval Gevangenpoort (Prison Gate), shot a picture of an elegantly dressed older woman and three boys in their early teens - her grandsons, Dirk, Alexander and Richard MacNeill - in joyful, even exuberant mood. The Second World War, the German invasion of the Netherlands and the subsequent 'loss' of the Indies, all of which would further re-shape the MacNeill family's trajectory, were only a very few years away, but in this photograph, at least, that corner had yet to be turned....

\section{Conclusion: The Multiplexity of Diaspora}

The immediate context of the story of Johanna Bezoet de Bie and Alexander MacNeill is the nexus between the extensive creole Dutch communities

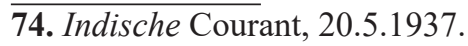




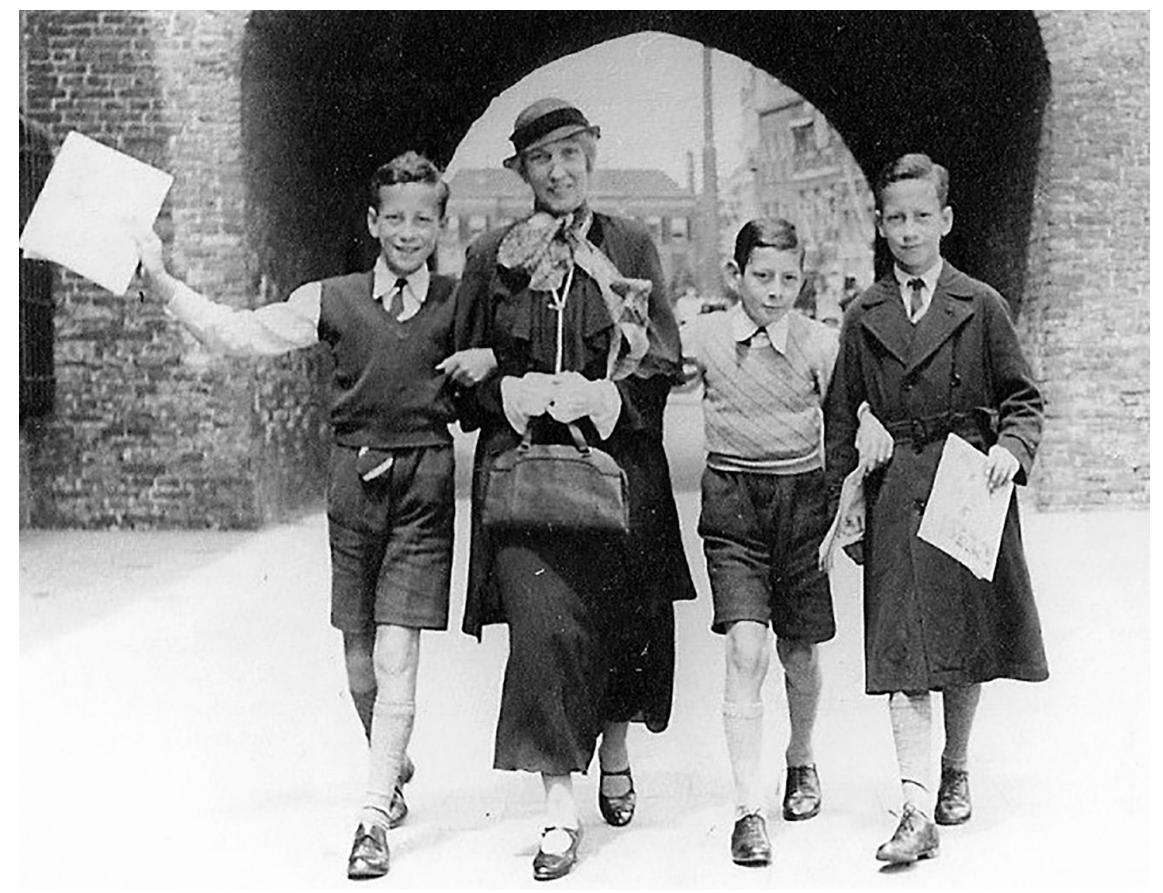

Fig. 24. Back in The Hague ca. 1938: Johanna Bezoet de Bie and her grandchildren.

of the Indies and their counterparts in the metropolitan Netherlands. In this particular case, it has been suggested, the two individuals concerned experienced the Indies, not as a place to settle but as the foundation for a 'return' to the metropolis after a necessary sojourn in what was, nonetheless, the country of their birth and childhood. The couple's story is located, however, in an altogether broader frame, one that embraces not only Dutch diasporic communities but also the history of the Scots of the diaspora who found their way to 'the East' during the course of the 'long' nineteenth century. Bezoet de Bie, it has to be remembered, was married to an individual whose ethnic and cultural identification with the Indies and the Netherlands existed alongside a Scottish one. It was, moreover, a Scottishness that ranged across the generations and was not only maintained but also re-invigorated by his and Bezoet de Bie's descendants. Indeed, the grandchildren whom we have just seen in the photograph with their oma [grandmother] taken in The Hague late in the 1930s subsequently set about a rigorous reconstruction of the record of their Scots ancestry as reflected in extensive memoranda and the like that accompany the photographic 'archive' of the family's Indies years 
drawn upon in the preceding pages. As such, the Bezoet de Bie-MacNeill story adds a further - and very necessary - dimension to an understanding of the sheer multiplexity of diaspora: their story forms part of a fabric that had many threads - and to neglect it would be to miss one of those intersections in social history at which the purely quantitative must cede some space to the 'merely' qualitative. 